\title{
Public Participation in the General Elections of India: An Overview since 1951
}

\author{
Ramesh Pandita \\ Assistant Librarian, BGSB University, Rajouri, Jammu \& Kashmir, India \\ R/o 274-C, Durga Nagar Sect. No I, P/o Roop Nagar, Jammu - 180013, \\ E-mail address: rameshpandita90@gmail.com
}

\begin{abstract}
Keywords: India, Democracy, Electoral Process, General Elections, Federal Structure, Multi Party System, Voter Turnout
\end{abstract}

\begin{abstract}
Democratic process of any country is based on the participation of the public to form the government through their elected representatives, and the nation having an electoral system in place to choose their representatives can be termed as a nation living true to its democratic essence, while as, the nation elusive of ground level public participation in forming governments can never be termed as living true to democratic colour. The present study is an attempt to understand the electoral process of India, the public participation in the democratic process of the country, which is already fifteen general elections old, lasted over the period 1951 to 2014 . Attempt has been made to understand the areas like, growth of parties over the period of time, seat distribution, reservation of seats, electoral participation, polling stations, performance of major national political parties along with electoral turnout both collectively and on gender basis etc. Existence of the multi party system in India and the growth in parties over a period of time gets equally reflected by the fact that in 1951, 54 parties participated in the electoral process and the number grew up to 466 in 2014 , reflecting a growth of over $792 \%$. During all the general elections contested by candidates $77.43 \%$ contestants forfeited their deposits with an average of 135 political parties contested each general election. Over $80.45 \%$ elected candidates to the parliament during all the general elections held so far, represent national parties
\end{abstract}

\section{INTRODUCTION}

India is world's largest Democratic Republic, having a population of over 1.2 billion and still upholding and living true to its socialist, secular and democratic values. In terms of area, India is the seventh largest country in the world. India has a pluralistic social setup, having diversity at almost every front, be it racial, cultural, religious, and ethnic. The linguistic diversity of the country gets assessed by the fact that over 1600 languages are spoken across the length and breadth of the county. Indian lies to the north of the equator between $6^{\circ} 44^{\prime}$ and $35^{\circ} 30^{\prime}$ north latitude and $68^{\circ} 7^{\prime}$ and $97^{\circ} 25^{\prime}$ east longitude ${ }^{[1]}$ and is located in South Asia, having a federal structure of governance. The modern India is being seen as come into existence on August 15, 1947, after attaining the independence from Britishers and since then democracy has moved on by conducting free and fair elections at regular intervals of time as per the electoral laws of the country enshrined in the constitution, by the election commission of a county, which is a constitutional body.

Election Commission of India is the sole authority vested with the superintendence to conduct general elections (Elections to the Parliament), to the legislature of every state and to the offices of President and Vice-President of India. Election Commission of India is the constitutional body of permanent nature, established on January $25,1950^{[2]}$. The election commission of India comprises of the Chief Election Commission and two Election Commissioners duly appointed by the President for a period of six years or up to the age of 65 years, whichever is earlier. The stature and other perks of election commissioners is at par with that of Judges of the Supreme Court of India and the Chief Election Commissioner of India can be removed from his office only through impeachment by Parliament. It is mandatory for all political parties to register with the election commission of 
India, which grants the status of a party of being national or state level mostly depending upon the presence of that political party among masses.

The constitution of India recognizes the parliamentary system of governance which has a bicameral structure, consisting of the President and the two houses of the parliament, known as Rajya Sabha and the Lok Sabha ${ }^{[3]}$. Since the country recognizes the federal structure of governance as such each individual state of the county has its own legislature, where representatives are directly elected to the legislative assembly by people, however, when it comes to the parliamentary elections in each state elects its public representatives in the parliament, which is done in proportion to the population of that particular state or union territory.

India attained its freedom on August 15, 1947, the first general elections to first Lok Sabha of the country were held in the year 1951, under the supervision of the election commissioner of India. So far India has undergone through 16 general elections. Accordingly, in the present study attempt has been made to undertake the analysis of all the general elections held in India since 1951 as per the objectives of the study. To undertake the study data has been retrieved from the official website of the Election Commission of India on August 21, $2015^{[4]}$, accessible at http://eci.gov.in/eci_main1/ElectionStatistics.aspx. The present study is an overview of all the general elections held in India since its attaining independence. Every attempt has been made to analyze the data in most convenient and easy to understand method. Most of analysis has been carried out as per the objectives of the study; however, during the course of analysis all such aspects have been put forth, which serve the purpose of present study in one or the other way.

\section{BRIEF MODERN HISTORY OF INDIA}

Not going into that detailed historical account, Indian mainly remained under the siege of Mughal Rulers. India saw the beginning of Mughal Empire in the year 1527 when Babar the Mugal monarch from Mangol came to power. The Mughal dynasty rose to its best during the reign of Akbar, who is being seen as one of the ablest rulers Mughal dynasty ever produced and the dynasty ultimately crumbled with the death of Auragzed in the year $1707^{[5]}$. Although East India Company set its base in Indian in Surat, Gujarat in the year 1610 by chasing away Portuguese naval squadron, but the freedom struggle in India against Bristishers begun in the year 1857 revolt, only for the fact that East India Company, which entered in India mainly with the intentions of trade ultimately ended up with taking over the whole of India. All this ultimately led to the rise of freedom struggle in India which lasted nearly for over 90 years, as India ultimately attained freedom on August 15, 1947.

\section{INDIAN PARLIAMENT \& ITS COMPOSITION}

The Structure of Indian Parliament as laid down in a country's constitution is bicameral in nature, consisting of the President and the two houses Rajya Sabha (the upper house or the Council of States) and the Lok Sabha (the lower house or the House of the People) ${ }^{[6]}$.

Rajya Sabha: - Rajya Sabha consists of a maximum 250 members, of which 12 are nominated by the President having special knowledge or practical experience in areas like, Literature, Science, Art or Social Services and remaining members are from the states and union territories generally in proportion its population, with at least one member from each state and union territory, having a minimum age of 30 years ${ }^{[7]}$. The representatives of the state are elected by the elected members of the Legislative Assembly through the single transferable vote system.

Lok Sabha: - Lok Sabha as referred to above is also known as the lower house of the parliament or the house of the people with a maximum strength of 552 members of which 530 represent the state, 20 represent Union Territories. Also, not more than two members of Anglo-Indian Community is nominated by the president, if the community is not adequately represented in the house. The present Lok Sabha consists of 545 members, including two nominated members. The minimum age as fixed under the constitution, one has to be at least 25 years old to be the member of Lok Sabha. 
All the members of Lok Sabha are chosen by the people directly through the electoral process for a period of five years, unless sooner dissolved. The first general elections were held in India in the year 1951, followed by subsequent elections held during the year 1957, 1962, 1967, 1972, 1977 , 1980, 1984, 1989, 1991, 1996, 1998, 1999, 2004, 2009 and $2014^{[8]}$.

\section{REVIEW OF LITERATURE}

Political analysts and researchers all across the globe have undertaken studies related to the electoral process of various global democracies from time to time. Most of these studies undertaken revolve round analyzing the aspects like governance system of a particular country, the electoral process, voter turnout, bi-party or multi-party system and various other things which interests a researcher or an analyst.

Lean and Gerring (2013) undertook a study on Liberia's 2011 General Elections which has a presidential form of government and is divided into 15 counties, having two tier electoral systems and the distribution of seats is based on in proportion to population which varies from two 2 to 17 seats. In all, $76.12 \%$ voters turned out was recorded during the 2011 general polls in Liberia, where more than 16 parties were in the fray for presidential and vice presidential candidates. The representatives are generally chosen for a period of six years term ${ }^{[9]}$.

Reif Karlheinz (2013) ${ }^{[10]}$ undertook a study of the national electoral cycles and European elections 1979 and 1984 and found that government parties irrespective of pro or anti European lost the 1984 elections badly, which as a result appeared more a test of opinion on domestic politics. Gallagher (2013) ${ }^{[11]}$ undertook a study on the proportionality, disproportionality and electoral systems, where in author advocates of applying different indices, which maximize and minimize the proportionality and disporoportionality means and observed that while applying these means to his study showed high correlation between the rankings produced.

Abramson et al (2013) ${ }^{[12]}$ studied the different voting rules of 2010 British general elections and found that 2010 general elections were historical in British history for the fact that these elections resulted in hung Parliament first time in over a generation. The study further raised questions over the heightened debate over the fairness and utility of counties centuries' old fist-pastthe-post (FPTP). Haughton and Kar_sovec (2013) ${ }^{[13]}$ undertook the study of the 2011 general elections in Slovenia, the scholars in their study made a general observation about role of smaller parties in politics, the formation of coalition government and how actually, the people are ready to throw away corrupt and incompetent politicians. Researchers further observed that how new entrants in politics find places for themselves on just and genuine issues if raised aptly in their manifestos and how voters are actually ready to get carried away with such issues which are pertinent and interest them the most.

Mueller and Dardanelli (2013) ${ }^{[14]}$ studied the 2011 executive and parliamentary elections in Switzerland, the researchers in their study dubbed these Swiss elections as a significant turning point in the political history of Switzerland, as the political practices which lasted in the country for over two decades came to an end and almost heralded an era which backs to late 1950's to mid 1990's.

Miwa Hiroki (1997) ${ }^{[15]}$ studied the 1996 general elections in India, in which he highlighted about the phase of economic liberalization of India, where the devaluation of the rupee was adopted to give boost to Indian trade and get finances form IMF and World Bank. Performance of INC in 1996 general elections was abysmal as it emerged as the second largest party with 140 seats, while as BJP emerged the single largest party with 161 seats. Congress was down by 104 seats form 1991 general elections while as BJP was up with 41 seats. Similar electoral studies have been conducted in the areas of women's participation in the electoral process of the country, and the assembly and general elections conducted in the state of Jammu \& Kashmir, India, (Pandita: 2014, 2015) ${ }^{[16,17,18]}$.

Tinker and Walker (1956) ${ }^{[19]}$ undertook a study on the first general elections of India and Indonesia, researchers in their findings observed that the results of the elections were on expected lines, as INC emerged the single largest party in India with $45.10 \%$ vote share and $74.43 \%$ seat share. The researchers in their study also made observations about the efficiency of the functioning 
of the election commission of India, which within 2 years of its setup conducted successful elections in the country, which indeed was the accepted mode of Britishers.

Sudipta Kaviraj (2007) ${ }^{[20]}$ undertook a study on the general elections of India and made observations that vote share of congress has steadily declined from $47.8 \%$ in 1957 to $37.6 \%$ in 1991 except in 1984 in which party secured $48.1 \%$ after the death of Smt. Indira Gandhi. The Vote share of congress fell to $34.3 \%$ after the emergency in 1977. Kumar (2002) ${ }^{[21]}$ published his work in economic and political weekly about reforming Indian Electoral Process in which author shows reservations with the proposal made on the disclosure of candidates and was of the view that ambiguities in the bill need to be removed. Kothari R (1967) ${ }^{[22]}$ in her article on the Congress 'System' in India talked about the multi-party system of India verses one party system

\section{OBJECTIVES OF THE STUDY}

- To study and understand the electoral process of India, which is more a nation of multi cultures, multi linguistic, multi religions and of course of the multi party political system

- To examine the general election trend of the country where population runs over 1.2 billion people and the voter turnout thereof

- To quantify the growth of political parties, both at the national and federal level, growth of electors, contestants, political reservations etc.

- To analyse the strengths and weakness of major national political parties, both in terms of their performance, their presence among masses, percentage of seats contested, percentage of success, the percentage of votes secured and also the percentage of candidates who forfeited their deposits.

\section{METHODOLOGY AND SCOPE}

The data for the present study was retrieved from the official website of the Election commission of India on August 21, 2015, which is more a case of data mining available at http://eci.gov.in/eci_main1/ElectionStatistics.aspx. The data retrieved was totally in raw and unstructured form as such was put in more helpful sequence by making it more structured so as to attain the objective of the study. All the relevant data was put to analysis by using various statistical tools and mathematical techniques.

The present study can be further extended to electoral process of the country at the federal level, the role of federal politics in the national polity of India and many similar aspects can be studied. Also on the similar lines electoral studies of other nations can be conducted whereby one can develop an idea about the reason of political instability among various nations and how far political stability is important for the growth and development of a nation in general and world in particular.

Limitations of the Study: - Although no major limitation came to the fore while retrieving data from the official website of the Election Commission of India, however, upon data structuration it emerged that data retrieved for the year 1951 and 1957 was inadequate in many places and accordingly the analysis under few tables has been carried out without such data and the boxes there have been incorporated with NA (Data Not Available). Accordingly, analysis in such tables has been undertaken by excluding the columns without data and the average figures and percentage thereof drawn at such places is based on considering the rest of the columns only.

Discussion and Data Analysis: - Indian National Congress (INC) came into being on December 28, 1885 in Bombay to fight for India's Independence, but the party continued to survive after independence and become one of formidable political parties in India to which Mahatma Gandhi was not in favour of. Since INC survived and emerged as the single largest political party during all the elections contested by party post independence and remained at the helm of affairs for over almost 90\% of India's political rule. Although left parties like Communist Party of India (CPI) and Communist Party of India, Marxist (CPM) had been contesting general elections in country from 
the very beginning of the electoral process but could not make any significant impact to entice voters of the country against the formidable and strong INC. Of the late Bhartiya Janta Party (BJP) has emerged as strongest opposition party in the Indian polity and is gradually making its mark towards ruling the nation, to which it had already two brief stints during the 1991 and 1996 general elections. The role of other smaller political parties of both national and state level cannot be undermined, as these parties have proven to be the king-maker in the prevailing coalition political culture of the country, which more or less has become the order of the day of Indian polity especially after 1991 .

The data retrieved from the official website of the Election Commission of India was put to analysis by employing statistical tools and techniques. To perform simple expressions like addition, subtraction, drawing percentage, etc. MS excel was equally put into use. Percentage at most of the places has been drawn up to two decimal places and the average figures at few places have been rounded off either to previous highest or next higher figure mostly based on below and above .5 expressions.

Table-1 Distribution of Elections and Participation of parties

\begin{tabular}{|c|c|c|c|c|c|}
\hline Year & Seats & $\begin{array}{c}\text { National } \\
\text { Parties (\%) }\end{array}$ & $\begin{array}{c}\text { State Parties }+ \\
\text { Independents } \\
(\mathbf{\%})\end{array}$ & Total & $\begin{array}{c}\text { Corresponding } \\
\text { Growth (\%) }\end{array}$ \\
\hline 1951 & $\# 489$ & $14(25.92)$ & $40(74.08)$ & 54 & - \\
\hline 1957 & $\# 494$ & $4(25.00)$ & $12(75.00)$ & 16 & $-38(-70.37)$ \\
\hline 1962 & 494 & $6(21.42)$ & $22(78.58)$ & 28 & $12(75.00)$ \\
\hline 1967 & 520 & $7(26.92)$ & $19(73.08)$ & 26 & $-2(-7.14)$ \\
\hline 1971 & 518 & $8(14.81)$ & $46(85.19)$ & 54 & $28(107.69)$ \\
\hline 1977 & 542 & $5(14.28)$ & $30(85.72)$ & 35 & $-19(-35.18)$ \\
\hline 1980 & 529 & $6(16.66)$ & $31(83.34)$ & 36 & $1(2.85)$ \\
\hline 1984 & 514 & $7(20.58)$ & $27(79.42)$ & 34 & $-2(-5.55)$ \\
\hline 1989 & 529 & $8(7.01)$ & $106(92.99)$ & 114 & $80(235.29)$ \\
\hline 1991 & 521 & $9(6.12)$ & $137(93.88)$ & 147 & $33(28.94)$ \\
\hline 1996 & 543 & $8(3.80)$ & $202(96.20)$ & 210 & $63(42.85)$ \\
\hline 1998 & 543 & $7(3.95)$ & $170(96.05)$ & 177 & $-33(-15.71)$ \\
\hline 1999 & 543 & $7(4.11)$ & $163(95.89)$ & 170 & $-7(-3.95)$ \\
\hline 2004 & 543 & $6(2.59)$ & $225(97.41)$ & 231 & $61(35.88)$ \\
\hline 2009 & 543 & $7(1.92)$ & $357(98.08)$ & 364 & $133(57.57)$ \\
\hline 2014 & 543 & $6(1.27)$ & $466(98.72)$ & 472 & $108(29.67)$ \\
\hline Avg & & $\mathbf{7 . 1 8}$ & $\mathbf{1 2 8}$ & $\mathbf{1 3 5 . 5}$ & $\mathbf{2 6 . 1 2 ( 2 9 . 8 6 )}$ \\
\hline
\end{tabular}

\# - Including double and triple constituencies 


\section{No of parties}

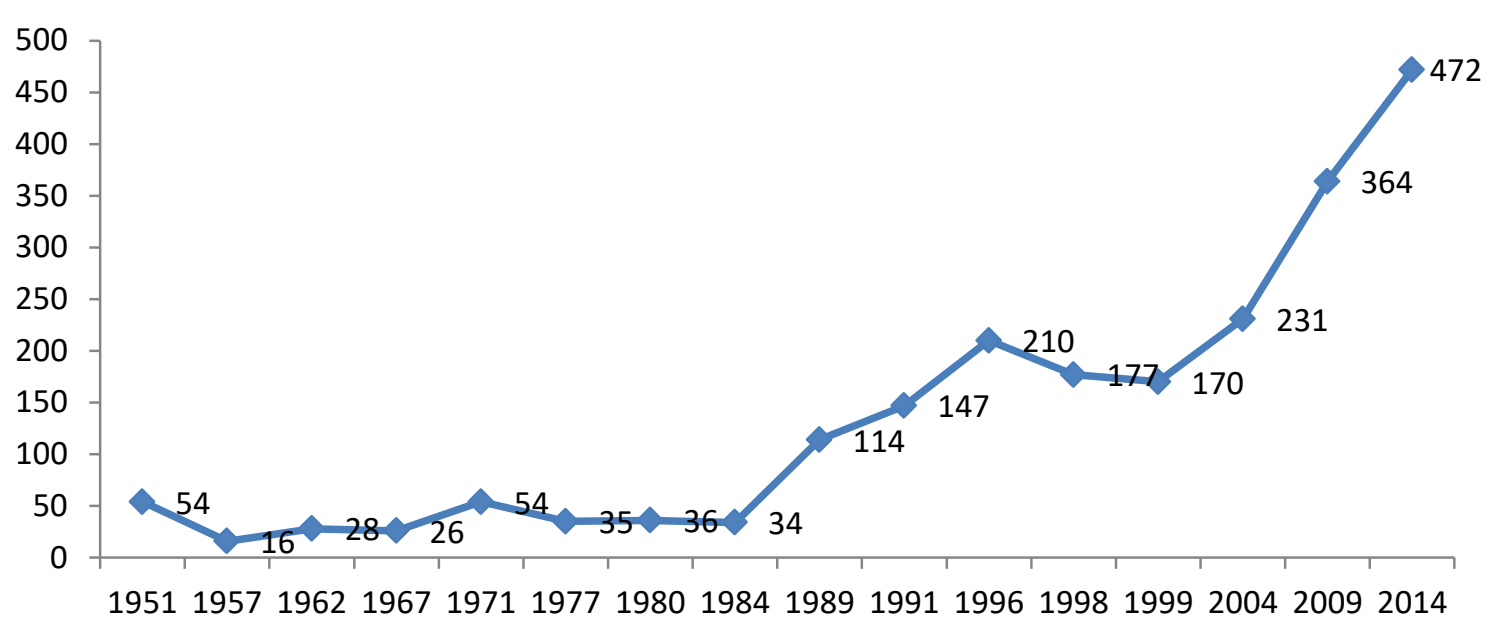

Figure 1 Growth of Political Parties During Each General Election.

As reflected, a considerable growth can be observed in the state political parties over a period of time, which on the contrary is missing when taken the case of national political parties of India. In 1951 a maximum of 14 national political parties were recognized by the Election Commission of India and contested the general elections, while as during the rest 15 general elections the number of national political parties which contested elections remained below 10, with overall average participation of 7.18 national level political parties in each general election. On average 128 state level political parties and independents contested each general election in India. A minimum of 12 state level political parties contested general elections during the year 1957 and a maximum of 466 parties in 2014. On average 135.50 political parties contested each general election in India. The overall corresponding growth of political parties participated in each general election showed a mixed trend, however, on average, $29.86 \%$, corresponding growth was recorded in participating political parties during each general election.

Table-2 Number and Type of Constituencies

\begin{tabular}{|c|c|c|c|c|}
\hline \multirow{2}{*}{ Year } & \multirow{2}{*}{ Seats } & \multicolumn{3}{|c|}{ Seat Distribution } \\
\cline { 3 - 5 } & & Gen (\%) & SC (\%) & ST (\%) \\
\hline 1951 & $\# 489$ & $391(79.95)$ & $72(14.72)$ & $26(5.31)$ \\
\hline 1957 & $\# 494$ & $387(79.14)$ & $76(15.54)$ & $31(6.33)$ \\
\hline 1962 & 494 & $385(77.93)$ & $79(15.99)$ & $30(6.07)$ \\
\hline 1967 & 520 & $406(78.07)$ & $77(14.80)$ & $37(7.11)$ \\
\hline 1971 & 518 & $406(78.37)$ & $76(14.67)$ & $36(6.94)$ \\
\hline 1977 & 542 & $426(78.59)$ & $78(14.39)$ & $38(7.01)$ \\
\hline 1980 & 529 & $422(77.85)$ & $79(14.57)$ & $41(7.56)$ \\
\hline 1984 & 514 & $401(78.01)$ & $75(14.59)$ & $38(7.39)$ \\
\hline 1989 & 529 & $412(77.88)$ & $78(14.74)$ & $39(7.37)$ \\
\hline 1991 & 521 & $407(77.67)$ & $76(14.50)$ & $41(7.82)$ \\
\hline 1996 & 543 & $423(77.90)$ & $79(14.54)$ & $41(7.55)$ \\
\hline 1998 & 543 & $423(77.90)$ & $79(14.54)$ & $41(7.55)$ \\
\hline 1999 & 543 & $423(77.90)$ & $79(14.54)$ & $41(7.55)$ \\
\hline 2004 & 543 & $423(77.90)$ & $79(14.54)$ & $41(7.55)$ \\
\hline 2009 & 543 & $412(75.87)$ & $84(15.46)$ & $47(8.65)$ \\
\hline 2014 & 543 & $412(75.87)$ & $84(15.46)$ & $47(8.65)$ \\
\hline Avg & & $\mathbf{4 0 9 ( 7 7 . 9 2 )}$ & $\mathbf{7 8 ( 1 4 . 8 4 )}$ & $\mathbf{3 8 . 4 3 ( 7 . 2 7 )}$ \\
\hline
\end{tabular}




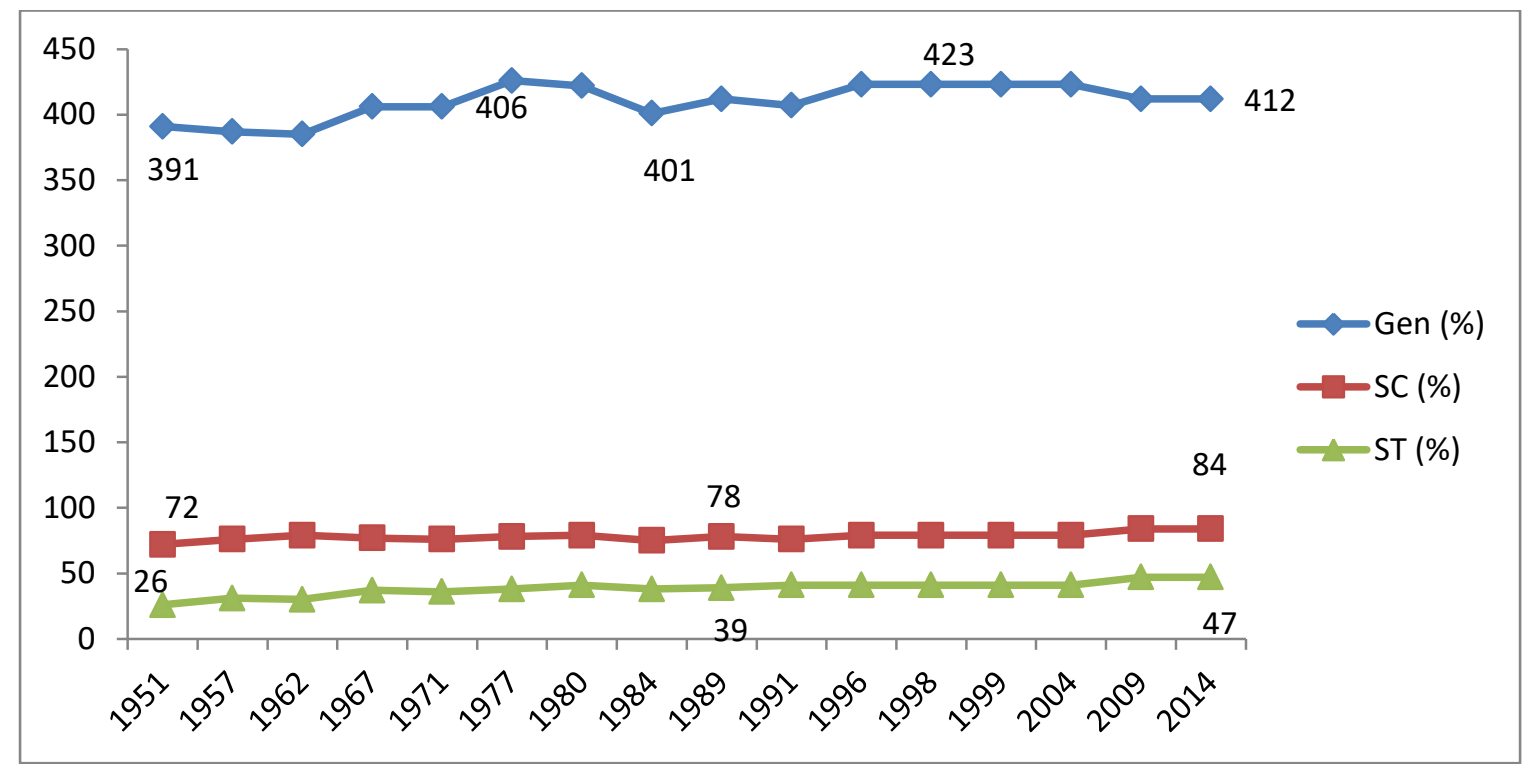

Figure 2 Reservation of constituencies for socially disadvantaged sections and general people.

With the view to empower the backward sections of the Indian society, due political reservations were given to Scheduled Castes (SC) and Scheduled Tribes (ST) of the country from the very beginning of the democratic process of the country. Political reservations to these two main socially disadvantaged sections of the Indian society were given on the basis of their population. Given this fact, we can see on average $14.84 \%$ parliamentary seats were reserved for scheduled casts and $7.27 \%$ for scheduled Tribes during each general election. Over a period of time the seats reserved for both the backward sections of society have been increased proportionately owing to the increase in total seats.

Table-3 Candidates per Constituency and their Growth

\begin{tabular}{|c|c|c|c|c|c|c|}
\hline \multirow{2}{*}{ Year } & \multirow{2}{*}{$\begin{array}{c}\text { Total } \\
\text { Seats }\end{array}$} & \multicolumn{4}{|c|}{ Candidate Fielded } & \multirow{2}{*}{$\begin{array}{c}\text { Corresponding } \\
\text { Growth (\%) }\end{array}$} \\
\cline { 3 - 6 } & & Min & Max & Avg & Total & - \\
\hline 1951 & $\# 489$ & 1 & 14 & 4.67 & 1874 & - \\
\hline 1957 & $\# 494$ & 1 & 13 & 3.77 & 1519 & $-355(-18.94)$ \\
\hline 1962 & 494 & 1 & 11 & 4.02 & 1985 & $466(30.67)$ \\
\hline 1967 & 520 & 1 & 14 & 4.56 & 2369 & $384(19.34)$ \\
\hline 1971 & 518 & 1 & 16 & 5.37 & 2784 & $415(17.51)$ \\
\hline 1977 & 542 & 1 & 14 & 4.16 & 2439 & $-345(-12.39)$ \\
\hline 1980 & 529 & 1 & 39 & 8.57 & 4629 & $2190(89.79)$ \\
\hline 1984 & 514 & 2 & 42 & 10.33 & 5312 & $683(14.75)$ \\
\hline 1989 & 529 & 1 & 122 & 11.64 & 6160 & $848(15.96)$ \\
\hline 1991 & 521 & 2 & 105 & 16.64 & 8668 & $2508(40.71)$ \\
\hline 1996 & 543 & 2 & 480 & 25.69 & 13952 & $5284(60.95)$ \\
\hline 1998 & 543 & 2 & 34 & 8.75 & 4750 & $-9202(-65.95)$ \\
\hline 1999 & 543 & 2 & 32 & 8.56 & 4648 & $-102(-2.14)$ \\
\hline 2004 & 543 & 2 & 35 & 10.01 & 5435 & $787(16.93)$ \\
\hline 2009 & 543 & 3 & 43 & 14.86 & 8070 & $2635(32.65)$ \\
\hline 2014 & 543 & 2 & 42 & 15.19 & 8251 & $181(2.19)$ \\
\hline Avg & & $\mathbf{1 . 5 6}$ & $\mathbf{6 6}$ & $\mathbf{9 . 7 9}$ & $\mathbf{5 1 7 7}$ & $\mathbf{3 9 8 . 5 6 ( 1 5 . 1 2 )}$ \\
\hline
\end{tabular}

\# - Including double and triple constituencies 


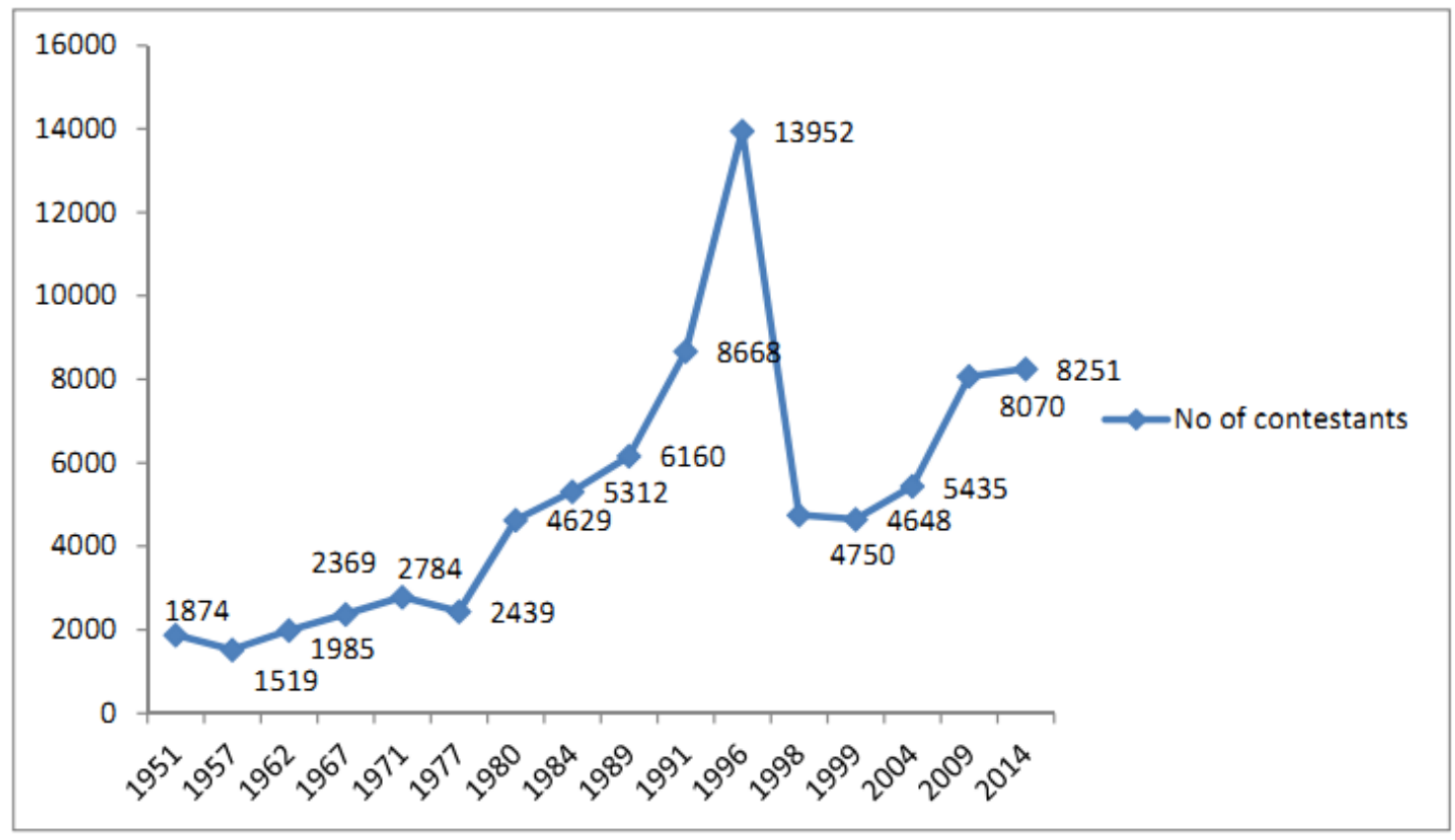

Figure 3 Growth of contestants during each general election.

In 1951, 1874 candidates contested elections on 489 seats, which came down to 1519 candidates who contestants on 494 seats in the year 1957, which is also the minimum number of candidates who contested general elections in India during its entire electoral history. From 1962 onwards the number of candidates contesting elections kept on increasing from election to election. Except for the election years 1957, 1977, 1998 and 1999 an increase in the number of candidates was witnessed during all other elections. A maximum of 13952 candidates contested elections on 543 seats in the year 1996 and sharp decline can be observed in the number of contesting candidates thereafter. During the period of study, a minimum of 1 and a maximum of 480 candidates have contested on a single seat, while as on average during all the elections under study, a minimum of 1.56 and a maximum of 66 candidates contested on single seat, with an average of 9.79 candidates per constituency/seat.

Table-4 Distribution of Polling Station with Average Electors

\begin{tabular}{|c|c|c|c|c|c|c|}
\hline Year & Seats & $\begin{array}{c}\text { No of } \\
\text { polling } \\
\text { Stations }\end{array}$ & $\begin{array}{c}\text { Corresponding } \\
\text { Growth (\%age) }\end{array}$ & $\begin{array}{c}\text { Average } \\
\text { Polling } \\
\text { Stations }\end{array}$ & Total Electors & $\begin{array}{c}\text { Average } \\
\text { Electors per } \\
\text { Polling Station }\end{array}$ \\
\hline 1951 & $\# 489$ & NA & - & - & 173212343 & - \\
\hline 1957 & $\# 494$ & NA & - & - & 193652179 & - \\
\hline 1962 & 494 & 238031 & - & 481.84 & 216361569 & 908 \\
\hline 1967 & 520 & 243693 & $5662(2.37)$ & 468.64 & 250207401 & 1026 \\
\hline 1971 & 518 & 342918 & $99225(40.71)$ & 662.00 & 274189132 & 799 \\
\hline 1977 & 542 & 373910 & $30992(9.03)$ & 689.87 & 321174327 & 858 \\
\hline 1980 & 529 & 436813 & $62903(16.82)$ & 825.73 & 356205329 & 815 \\
\hline 1984 & 514 & 479512 & $42699(9.77)$ & 932.90 & 379540608 & 791 \\
\hline 1989 & 529 & 580798 & $101286(21.12)$ & 1097.91 & 498906129 & 859 \\
\hline 1991 & 521 & 576353 & $-4445(-0.76)$ & 1106.24 & 498363801 & 864 \\
\hline 1996 & 543 & 767462 & $191109(33.15)$ & 1413.37 & 592572288 & 772 \\
\hline 1998 & 543 & 772681 & $5219(0.68)$ & 1422.98 & 605880192 & 784 \\
\hline 1999 & 543 & 774651 & $1970(0.25)$ & 1426.61 & 619536847 & 799 \\
\hline 2004 & 543 & 687473 & $-87178(-11.25)$ & 1266.06 & 671487930 & 976 \\
\hline 2009 & 543 & 830866 & $143393(20.85)$ & 1530.13 & 716985101 & 862 \\
\hline 2014 & 543 & 927553 & $96687(11.63)$ & 1708.20 & 834082812 & 899 \\
\hline Avg & & $\mathbf{5 0 2 0 4 4}$ & $\mathbf{4 3 0 9 5 ( 9 . 6 4 )}$ & $\mathbf{9 3 9 . 5 3}$ & $\mathbf{4 5 0 1 4 7 3 7 4}$ & $\mathbf{8 5 8}$ \\
\hline
\end{tabular}




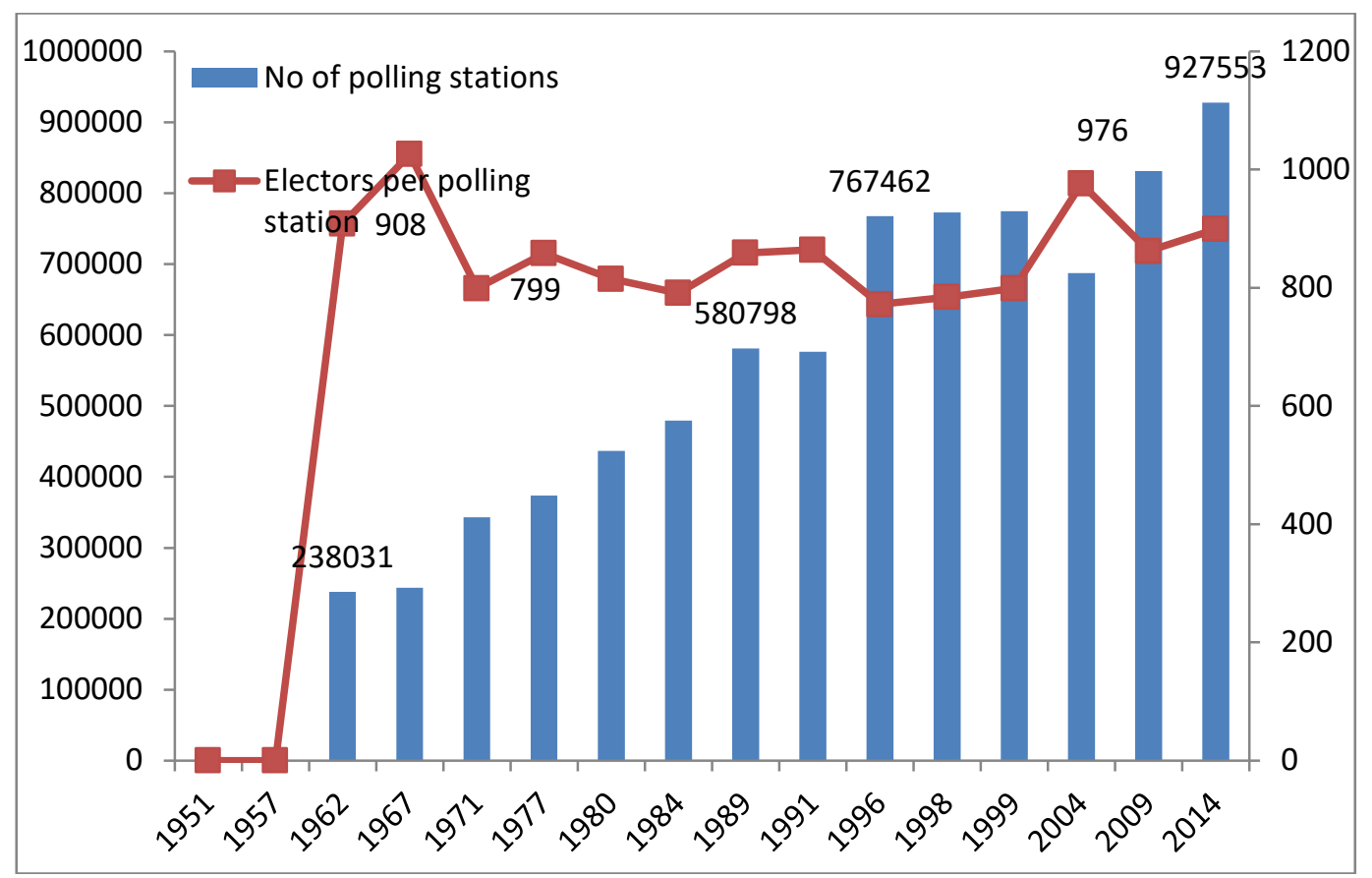

Figure 4 Number of electros against each polling station

With the increase in the electors of the country, a proportionate increase in the number of polling stations can be observed as we move from one general election to another. In 1962 on average, there were 481.84 polling stations against each parliamentary seat with an average of 908 electors to each polling station, the number grew on average to 1708.2 polling stations for each seat with an average of 899 electors to each polling station in 2014. As we move from 1951 to 2014, there has been consistent and constant growth in the number of polling stations during all the 16 general elections held in India. On average 502044 polling stations were in place during all the general elections across the country with average 939.53 polling stations per seats for 858 average electors per polling station. In terms of corresponding growth in the number of polling stations from the previous elections except for the year 1991 and 2004 positive growth was observed.

Table-5 Distribution of Seats won by parties against the candidate fielded and their success percentage

\begin{tabular}{|c|c|c|c|c|c|c|c|c|c|}
\hline \multirow{2}{*}{ Year } & \multirow{2}{*}{$\begin{array}{l}\text { No of } \\
\text { Seats }\end{array}$} & \multicolumn{4}{|c|}{ Candidates fielded } & \multicolumn{4}{|c|}{ Candidates Elected \& Success Percentage } \\
\hline & & $\mathbf{N P}$ & SP & IND & Total & NP (\%) & SP (\%) & IND (\%) & Total (\%) \\
\hline 1951 & $\# 489$ & 1217 & 124 & 533 & 1874 & $418(34.35)$ & $34(27.42)$ & $37(6.94)$ & 489 \\
\hline 1957 & $\# 494$ & 919 & 119 & 481 & 1519 & $421(45.81)$ & $31(26.50)$ & $42(8.73)$ & 494 \\
\hline 1962 & 494 & 1269 & 237 & 479 & 1985 & $440(34.67)$ & $34(14.34)$ & $20(4.18)$ & 494 \\
\hline 1967 & 520 & 1342 & 161 & 866 & 2369 & $440(32.79)$ & $45(27.95)$ & $35(4.04)$ & 520 \\
\hline 1971 & 518 & 1223 & 427 & 1134 & 2784 & $451(36.88)$ & $53(12.41)$ & $14(1.23)$ & 518 \\
\hline 1977 & 542 & 1060 & 155 & 1224 & 2439 & $481(45.38)$ & $52(33.54)$ & $9(0.74)$ & 542 \\
\hline 1980 & 529 & 1541 & 262 & 2826 & 4629 & $485(31.47)$ & $35(13.35)$ & $9(0.32)$ & 529 \\
\hline 1984 & 514 & 1244 & 277 & 3791 & 5312 & $451(36.25)$ & $58(20.93)$ & $5(0.13)$ & 514 \\
\hline 1989 & 529 & 1378 & 1069 & 3713 & 6160 & $471(34.18)$ & $46(4.30)$ & $12(0.32)$ & 529 \\
\hline 1991 & 521 & 1822 & 1332 & 5514 & 8668 & $466(25.58)$ & $54(4.05)$ & $1(0.02)$ & 521 \\
\hline 1996 & 543 & 1817 & 1499 & 10636 & 13952 & $403(22.18)$ & $131(8.73)$ & $9(0.08)$ & 543 \\
\hline 1998 & 543 & 1493 & 1342 & 1915 & 4750 & $387(25.92)$ & $150(11.17)$ & $6(0.31)$ & 543 \\
\hline 1999 & 543 & 1299 & 1404 & 1945 & 4648 & $369(28.41)$ & $168(11.96)$ & $6(0.30)$ & 543 \\
\hline 2004 & 543 & 1351 & 1699 & 2385 & 5435 & $364(26.94)$ & $174(10.24)$ & $5(0.21)$ & 543 \\
\hline 2009 & 543 & 1623 & 2616 & 3831 & 8070 & $376(23.16)$ & $158(6.03)$ & $9(0.23)$ & 543 \\
\hline 2014 & 543 & 1591 & 3426 & 3234 & 8255 & $342(21.49)$ & $198(5.77)$ & $3(0.09)$ & 543 \\
\hline Avg & & $\begin{array}{c}22189 \\
(26.78)^{\wedge}\end{array}$ & $\begin{array}{c}16149 \\
(19.49)^{\wedge}\end{array}$ & $\begin{array}{c}44507 \\
(53.72)^{\wedge}\end{array}$ & 82845 & $\begin{array}{c}6765(30.48) * \\
\#(80.45)\end{array}$ & $\begin{array}{c}1421(8.79) * \\
\#(16.90)\end{array}$ & $\begin{array}{c}222(0.49) * \\
\#(2.64)\end{array}$ & $\begin{array}{c}8408(10.15)^{*} \\
\#(100)\end{array}$ \\
\hline
\end{tabular}

NP-National Parties, SP-State Parties, IND-Independents

Note- \# represents the aggregate share percentage of seats won by parties during all elections

* represents the aggregate success percentage of candidates among the fielded candidates

$\wedge$ Average Participation Percentage 
Above tabulation reflects the interesting facts about the performance of National and State level political parties of India during all the parliamentary elections contested so far. On average during all the general elections in India, national parties fielded $26.78 \%$ candidates, state parties $19.49 \%$ and independents $53.72 \%$ candidates, while as in terms of candidates elected, national parties have an almost loins share with $80.45 \%$, followed by state parties with share percentage of $16.90 \%$ and Independents $2.64 \%$. One more interesting fact which emerged out of above tabulation is about the success percentage of the candidates fielded. National parties here again show supremacy over other state parties and independents, with a success percentage of $30.48 \%$, followed by state parties with $8.79 \%$ and independents with meagre $0.49 \%$. While as, the success percentage of overall contesting candidates during all the elections held in India remained at $10.15 \%$.

Table-6 Performance of Leading National Parties

\begin{tabular}{|c|c|c|c|c|c|c|c|c|c|c|c|c|c|}
\hline \multirow[b]{2}{*}{ Year } & \multirow{2}{*}{$\begin{array}{l}\text { No of } \\
\text { Seats }\end{array}$} & \multicolumn{6}{|c|}{ Candidates fielded } & \multicolumn{6}{|c|}{ Candidates Elected \& Success Percentage } \\
\hline & & BJP & BSP & CPI & CPM & INC & ONP & BJP (\%) & $\begin{array}{l}\text { BSP } \\
(\%)\end{array}$ & CPI (\%) & CPM (\%) & INC (\%) & ONP (\%) \\
\hline 1951 & $\# 489$ & - & - & 49 & - & 489 & 689 & - & - & $16(32.65)$ & - & $364(75.99)$ & $38(5.51)$ \\
\hline 1957 & $\# 494$ & - & - & 110 & - & 490 & 319 & - & - & $27(24.54)$ & - & $371(75.71)$ & $23(7.21)$ \\
\hline 1962 & 494 & - & - & 137 & - & 488 & 644 & - & - & $29(21.16)$ & - & $361(73.97)$ & $50(7.76)$ \\
\hline 1967 & 520 & - & - & 109 & 59 & 516 & 658 & - & - & $23(21.10)$ & $19(32.20)$ & $283(54.84)$ & $\begin{array}{c}115 \\
(17.47)\end{array}$ \\
\hline 1971 & 518 & - & - & 87 & 85 & 441 & 610 & - & - & $23(26.43)$ & $25(29.41)$ & $352(79.81)$ & $51(8.36)$ \\
\hline 1977 & 542 & - & - & 91 & 53 & 492 & 424 & - & - & 7 (7.69) & $22(41.5)$ & $154(31.30)$ & $\begin{array}{c}298 \\
(70.28) \\
\end{array}$ \\
\hline 1980 & 529 & - & - & 47 & 64 & 492 & 938 & - & - & $10(21.27)$ & $37(57.81)$ & $353(71.74)$ & $85(9.06)$ \\
\hline 1984 & 514 & 224 & - & 61 & 59 & 491 & 409 & $2(0.89)$ & - & $6(9.83)$ & $22(37.28)$ & $404(82.28)$ & $17(4.15)$ \\
\hline 1989 & 529 & 225 & - & 50 & 64 & 510 & 529 & $85(37.77)$ & - & $\begin{array}{c}12 \\
(24.00)\end{array}$ & $33(51.56)$ & $197(38.62)$ & $\begin{array}{c}144 \\
(27.22)\end{array}$ \\
\hline 1991 & 521 & 468 & - & 42 & 60 & 487 & 775 & $\begin{array}{c}120 \\
(25.64) \\
\end{array}$ & - & 14 (33.33) & $35(58.33)$ & $232(47.63)$ & $65(8.38)$ \\
\hline 1996 & 543 & 471 & - & 43 & 75 & 529 & 699 & $\begin{array}{c}161 \\
(34.18)\end{array}$ & - & $12(27.9)$ & $32(42.66)$ & $140(26.46)$ & $58(8.29)$ \\
\hline 1998 & 543 & 388 & 251 & 58 & 71 & 477 & 248 & $\begin{array}{c}182 \\
(46.90)\end{array}$ & $5(1.99)$ & $9(15.51)$ & $32(45.07)$ & $141(29.55)$ & $18(7.25)$ \\
\hline 1999 & 543 & 339 & 225 & 54 & 72 & 453 & 156 & $\begin{array}{c}182 \\
(53.68) \\
\end{array}$ & $\begin{array}{c}14 \\
(6.22) \\
\end{array}$ & $4(7.40)$ & $33(45.83)$ & $114(25.16)$ & $22(14.10)$ \\
\hline 2004 & 543 & 364 & 435 & 34 & 69 & 417 & 32 & $\begin{array}{c}138 \\
(37.91) \\
\end{array}$ & $\begin{array}{c}19 \\
(4.36) \\
\end{array}$ & $10(29.41)$ & $43(62.31)$ & $145(34.77)$ & $9(28.12)$ \\
\hline 2009 & 543 & 433 & 500 & 56 & 82 & 440 & 112 & $\begin{array}{c}116 \\
(26.78)\end{array}$ & $\begin{array}{c}21 \\
(4.20)\end{array}$ & $4(7.14)$ & $16(19.51)$ & $206(46.81)$ & $13(11.60)$ \\
\hline 2014 & 543 & 428 & 503 & 67 & 93 & 464 & 36 & $\begin{array}{c}282 \\
(65.88)\end{array}$ & 0 & $\begin{array}{c}1 \\
(1.49) \\
\end{array}$ & $\begin{array}{c}9 \\
(9.67)\end{array}$ & $\begin{array}{c}44 \\
(9.48)\end{array}$ & $\begin{array}{c}6 \\
(16.66) \\
\end{array}$ \\
\hline Avg & & $\begin{array}{l}3340 \\
(371) \\
\end{array}$ & $\begin{array}{l}1914 \\
(382) \\
\end{array}$ & $\begin{array}{l}1095 \\
(68) \\
\end{array}$ & $\begin{array}{l}906 \\
(69)\end{array}$ & $\begin{array}{l}7676 \\
(479) \\
\end{array}$ & $\begin{array}{l}7278 \\
(454) \\
\end{array}$ & $\begin{array}{c}1268 \\
(37.96) \\
\end{array}$ & $\begin{array}{c}59 \\
(3.08) \\
\end{array}$ & $\begin{array}{c}207 \\
(18.90) \\
\end{array}$ & 358 (39.51) & $\begin{array}{c}3861 \\
(50.29) \\
\end{array}$ & $\begin{array}{c}1012 \\
(13.90) \\
\end{array}$ \\
\hline
\end{tabular}

Note-Average figures from candidates fielded have been rounded off either to the next higher or to previous highest

The tabulation is an assessment of the performance of five major national political parties of India on the basis of the candidates field by each party in each individual election and the candidates elected thereof. CPI and the INC are the only parties, who have been active in the Indian political process since the beginning of the electoral process of the country. CPM joined the race in the year 1967, followed by the BJP in the year 1984 and BSP in the year 1998. Presence and popularity of INC among the Indian masses cannot be ignored. From 1951 to 1984 INC always emerged as the dominant party with a success percentage of over 70\%, but as we move down from 1989 to 2009 there is a sharp decline in the performance of the INC as their winning percentage came down to nearly $30 \%$ and on aggregate if we see their success percentage during all the elections they contested remained $50.29 \%$, which still is much better to their rivals. CPI also showed declines from election to election and on average has a success percentage of $18.90 \%$. CPM almost remained consistent during all the elections the party contested, with an aggregate success percentage of $39.51 \%$. The BJP came on the national scene with a modest beginning with 2 seats in 1984 and had some mixed fortunes during the subsequent elections and the fact of the matter is party acted as the major opposition since 1989 and has an aggregate success percentage of $37.96 \%$. BSP as a party has a nationwide presence as the party remained successful in exploiting the cast card in the country, but not much to their success, as the party could garner only $3.08 \%$ aggregate success during all the elections it contested. 
Table-7 Deposits forfeited by Candidates

\begin{tabular}{|c|c|c|c|c|c|c|c|c|c|}
\hline \multirow{2}{*}{ Year } & \multirow{2}{*}{$\begin{array}{l}\text { No of } \\
\text { Seats }\end{array}$} & \multicolumn{4}{|c|}{ Candidates fielded } & \multicolumn{4}{|c|}{ Forfeited Deposits } \\
\hline & & $\mathbf{N P}$ & SP & IND & Total & NP (\%) & SP (\%) & IND (\%) & Total (\%) \\
\hline 1951 & $\# 489$ & 1217 & 124 & 533 & 1874 & $344(28.27)$ & $41(33.06)$ & $360(67.54)$ & $745(39.75)$ \\
\hline 1957 & $\# 494$ & 919 & 119 & 481 & 1519 & $130(14.14)$ & $40(33.61)$ & $324(67.35)$ & $494(32.52)$ \\
\hline 1962 & 494 & 1269 & 237 & 479 & 1985 & $362(28.52)$ & $116(48.94)$ & $378(78.91)$ & $856(43.12)$ \\
\hline 1967 & 520 & 1342 & 161 & 866 & 2369 & $390(29.06)$ & $66(40.99)$ & $747(86.25)$ & $1203(50.78)$ \\
\hline 1971 & 518 & 1223 & 427 & 1134 & 2784 & $359(29.35)$ & $282(66.04)$ & $1066(94.00)$ & $1707(61.31)$ \\
\hline 1977 & 542 & 1060 & 155 & 1224 & 2439 & $100(9.43)$ & $66(42.58)$ & $1190(97.22)$ & $1356(55.59)$ \\
\hline 1980 & 529 & 1541 & 262 & 2826 & 4629 & $444(28.81)$ & $179(68.32)$ & $2794(98.86)$ & $3417(73.81)$ \\
\hline 1984 & 514 & 1244 & 277 & 3791 & 5312 & $355(28.53)$ & $163(58.84)$ & $3745(98.78)$ & $4263(80.25)$ \\
\hline 1989 & 529 & 1378 & 1069 & 3713 & 6160 & $421(30.55)$ & $910(85.12)$ & $3672(98.89)$ & $5003(81.21)$ \\
\hline 1991 & 521 & 1822 & 1332 & 5514 & 8668 & $828(45.44)$ & $1161(87.16)$ & $5497(99.69)$ & $7486(86.36)$ \\
\hline 1996 & 543 & 1817 & 1499 & 10636 & 13952 & $897(49.36)$ & $1187(79.18)$ & $10604(99.69)$ & $12688(90.94)$ \\
\hline 1998 & 543 & 1493 & 1342 & 1915 & 4750 & $637(42.66)$ & $951(70.86)$ & $1898(99.11)$ & $3486(73.38)$ \\
\hline 1999 & 543 & 1299 & 1404 & 1945 & 4648 & $437(33.64)$ & 1035 (73.71) & $1928(99.12)$ & $3400(73.15)$ \\
\hline 2004 & 543 & 1351 & 1699 & 2385 & 5435 & $541(40.04)$ & $1307(76.92)$ & $2370(99.37)$ & $4218(77.60)$ \\
\hline 2009 & 543 & 1623 & 2616 & 3831 & 8070 & 779 (47.99) & $2244(85.77)$ & 3806 (99.34) & $6829(84.62)$ \\
\hline 2014 & 543 & 1591 & 3426 & 3234 & 8251 & $807(50.72)$ & $2975(86.83)$ & $3218(99.50)$ & $7000(84.83)$ \\
\hline $\begin{array}{l}\text { Avg } \\
\& \\
(\%)\end{array}$ & & $\begin{array}{c}22189 \\
(26.78)^{\wedge}\end{array}$ & $\begin{array}{c}16149 \\
(19.49)^{\wedge}\end{array}$ & $\begin{array}{c}44507 \\
(53.72)^{\wedge}\end{array}$ & 82845 & $\begin{array}{c}7831(35.29) * \\
\#(12.20)\end{array}$ & $\begin{array}{c}12723(78.78)^{*} \\
\#(19.83)\end{array}$ & $\begin{array}{c}43597(97.95) * \\
\#(67.95)\end{array}$ & $\begin{array}{c}64151(77.43) * \\
\#(100)\end{array}$ \\
\hline
\end{tabular}

NP-National Parties, SP-State Parties, IND-Independents

Note- \# represents the aggregate share percentage of candidates who forfeited deposits during all elections

* represents the aggregate percentage of candidates who forfeited deposits among the fielded candidates

$\wedge$ Average Participation percentage of parties

Above tabulation has been drawn to assess the percentage of candidates who forfeited their deposits both among National and State level political parties along with Independent candidates. While moving down from the 1951 general elections to 2009, one can see almost exponential growth in the number of candidates who contested elections. In all, 1874 candidates contested elections in the year 1951 on as many 489 seats and this number rose to 13952 candidates in the year 1996, which declined thereafter and in the year 2014 only 8251 candidates contested the elections on as many 543 seats. As was seen growth in the number of candidates contesting elections from election to election so was seen proportionate growth in the increase of the number of candidates who forfeited their deposits. If we look at the total figures of candidates contesting from all parties the number of candidates who forfeited their deposits grew from $39.75 \%$ candidates in 1951 to $84.83 \%$ candidates in 2014. On average, $35.29 \%$ candidates contesting from national parties forfeited their deposits, which stood $78.78 \%$ for candidates contesting from state parties and $97.95 \%$ candidates as independents. On average at gross national level, $77.43 \%$ candidates contesting elections from all the parties forfeited their deposits. Of all the candidates who forfeited their deposits during all the elections $12.20 \%$ candidates are from the national parties, $19.83 \%$ from state parties and $67.95 \%$ from independents.

Table-8 Percentage of Candidates of Major National Parties Who Forfeited Deposits

\begin{tabular}{|c|c|c|c|c|c|c|c|c|c|c|c|c|c|}
\hline \multirow[b]{2}{*}{ Year } & \multirow[b]{2}{*}{$\begin{array}{l}\text { No of } \\
\text { Seats }\end{array}$} & \multicolumn{6}{|c|}{ Candidates fielded } & \multicolumn{6}{|c|}{ Candidates Forfeited Deposits \& \%age } \\
\hline & & BJP & BSP & CPI & CPM & INC & ONP & BJP (\%) & $\begin{array}{l}\text { BSP } \\
(\%)\end{array}$ & $\begin{array}{l}\text { CPI } \\
(\%)\end{array}$ & $\begin{array}{c}\text { CPM } \\
(\%)\end{array}$ & $\begin{array}{l}\text { INC } \\
(\%)\end{array}$ & $\begin{array}{l}\text { ONP } \\
(\%)\end{array}$ \\
\hline 1951 & \#489 & - & - & 49 & - & 489 & 689 & - & - & $\begin{array}{c}8 \\
(16.33)\end{array}$ & - & $4(0.84)$ & $\begin{array}{c}332 \\
(48.18)\end{array}$ \\
\hline 1957 & \#494 & - & - & 110 & - & 490 & 319 & - & - & $\begin{array}{c}16 \\
(14.55)\end{array}$ & - & $2(0.41)$ & $\begin{array}{c}112 \\
(35.10)\end{array}$ \\
\hline 1962 & 494 & - & - & 137 & - & 488 & 644 & - & - & $\begin{array}{c}26 \\
(18.98)\end{array}$ & - & $3(0.61)$ & $\begin{array}{c}333 \\
(51.70)\end{array}$ \\
\hline 1967 & 520 & - & - & 109 & 59 & 516 & 658 & - & - & $\begin{array}{c}41 \\
(37.61)\end{array}$ & $\begin{array}{c}13 \\
(22.03)\end{array}$ & $7(1.36)$ & $\begin{array}{c}329 \\
(50.00)\end{array}$ \\
\hline 1971 & 518 & - & - & 87 & 85 & 441 & 610 & - & - & $\begin{array}{c}33 \\
(37.93)\end{array}$ & $\begin{array}{c}31 \\
(36.47)\end{array}$ & $4(0.91)$ & $\begin{array}{c}345 \\
(56.55)\end{array}$ \\
\hline
\end{tabular}




\begin{tabular}{|c|c|c|c|c|c|c|c|c|c|c|c|c|c|}
\hline 1977 & 542 & - & - & 91 & 53 & 492 & 424 & - & - & $\begin{array}{c}68 \\
(74.73) \\
\end{array}$ & $\begin{array}{c}9 \\
(16.98)\end{array}$ & $\begin{array}{c}18 \\
(3.66) \\
\end{array}$ & $\begin{array}{c}5 \\
(1.17)\end{array}$ \\
\hline 1980 & 529 & - & - & 47 & 64 & 492 & 938 & - & - & $\begin{array}{c}17 \\
(36.17)\end{array}$ & $\begin{array}{c}9 \\
(14.06)\end{array}$ & $7(1.42)$ & $\begin{array}{c}411 \\
(43.81)\end{array}$ \\
\hline 1984 & 514 & 224 & - & 61 & 59 & 491 & 409 & $\begin{array}{c}108 \\
(42.21)\end{array}$ & - & $\begin{array}{c}30 \\
(49.18)\end{array}$ & $\begin{array}{c}6 \\
(10.17)\end{array}$ & $2(0.41)$ & $\begin{array}{c}209 \\
(51.10)\end{array}$ \\
\hline 1989 & 529 & 225 & - & 50 & 64 & 510 & 529 & $\begin{array}{c}88 \\
(39.11)\end{array}$ & - & $\begin{array}{c}20 \\
(40.00)\end{array}$ & $5(7.81)$ & $5(0.98)$ & $\begin{array}{c}303 \\
(57.27)\end{array}$ \\
\hline 1991 & 521 & 468 & - & 42 & 60 & 487 & 775 & $\begin{array}{c}185 \\
(39.53)\end{array}$ & - & $\begin{array}{c}16 \\
(38.10)\end{array}$ & $\begin{array}{c}7 \\
(11.67) \\
\end{array}$ & $\begin{array}{c}60 \\
(12.32)\end{array}$ & $\begin{array}{c}560 \\
(72.25)\end{array}$ \\
\hline 1996 & 543 & 471 & - & 43 & 75 & 529 & 699 & $\begin{array}{c}180 \\
(38.22)\end{array}$ & - & $\begin{array}{c}22 \\
(51.16)\end{array}$ & $\begin{array}{c}22 \\
(29.33)\end{array}$ & $\begin{array}{c}127 \\
(24.01)\end{array}$ & $\begin{array}{c}546 \\
(78.11)\end{array}$ \\
\hline 1998 & 543 & 388 & 251 & 58 & 71 & 477 & 248 & $\begin{array}{c}57 \\
(14.69)\end{array}$ & $\begin{array}{c}176 \\
(70.12)\end{array}$ & $\begin{array}{c}40 \\
(68.97)\end{array}$ & $\begin{array}{c}20 \\
(28.17)\end{array}$ & $\begin{array}{c}153 \\
(32.08)\end{array}$ & $\begin{array}{c}193 \\
(77.82)\end{array}$ \\
\hline 1999 & 543 & 339 & 225 & 54 & 72 & 453 & 156 & $24(7.08)$ & $\begin{array}{c}154 \\
(68.44)\end{array}$ & $\begin{array}{c}39 \\
(72.22)\end{array}$ & $\begin{array}{c}20 \\
(27.78)\end{array}$ & $\begin{array}{c}88 \\
(19.43)\end{array}$ & $\begin{array}{c}112 \\
(71.79)\end{array}$ \\
\hline 2004 & 543 & 364 & 435 & 34 & 69 & 417 & 32 & $\begin{array}{c}57 \\
(15.66) \\
\end{array}$ & $\begin{array}{c}358 \\
(82.30) \\
\end{array}$ & $\begin{array}{c}19 \\
(55.88) \\
\end{array}$ & $\begin{array}{c}15 \\
(21.74)\end{array}$ & $\begin{array}{c}82 \\
(19.66) \\
\end{array}$ & $\begin{array}{c}10 \\
(31.25)\end{array}$ \\
\hline 2009 & 543 & 433 & 500 & 56 & 82 & 440 & 112 & $\begin{array}{c}170 \\
(39.26)\end{array}$ & $\begin{array}{c}410 \\
(82.00)\end{array}$ & $\begin{array}{c}41 \\
(73.21)\end{array}$ & $\begin{array}{c}29 \\
(35.36)\end{array}$ & $\begin{array}{c}71 \\
(16.13)\end{array}$ & $\begin{array}{c}58 \\
(51.78)\end{array}$ \\
\hline 2014 & 543 & 428 & 503 & 67 & 93 & 464 & 36 & $\begin{array}{c}62 \\
(14.48)\end{array}$ & $\begin{array}{c}447 \\
(88.86)\end{array}$ & $\begin{array}{c}57 \\
(85.07)\end{array}$ & $\begin{array}{c}50 \\
(53.76)\end{array}$ & $\begin{array}{c}178 \\
(38.36)\end{array}$ & $\begin{array}{c}13 \\
(36.11)\end{array}$ \\
\hline Avg & & $\begin{array}{l}3340 \\
(371)\end{array}$ & $\begin{array}{l}1914 \\
(382)\end{array}$ & $\begin{array}{l}1095 \\
(68)\end{array}$ & $\begin{array}{l}906 \\
(69)\end{array}$ & $\begin{array}{l}7676 \\
(479)\end{array}$ & $\begin{array}{l}7278 \\
(454)\end{array}$ & $\begin{array}{c}931 \\
(27.87)\end{array}$ & $\begin{array}{c}1545 \\
(80.72)\end{array}$ & $\begin{array}{c}493 \\
(45.02)\end{array}$ & $\begin{array}{c}236 \\
(26.04)\end{array}$ & $\begin{array}{c}811 \\
(10.56)\end{array}$ & $\begin{array}{c}3871 \\
(53.18)\end{array}$ \\
\hline
\end{tabular}

Note-Average figures from candidates fielded have been rounded off either to the next higher or to previous highest

Performance and the presence of political parties among the masses is also assessed by evaluating those weak areas wherein the party's performance may have remained below expected lines, one such measure is to undertake the analysis of candidates who forfeited their deposits during elections. In the above tabulation, analysis has accordingly been drawn to assess the percentage of candidates among major national political parties of India who forfeited their deposits. Strength and presence of INC among India masses get also reflected by the fact that during all the general elections contested by party only $10.56 \%$ contestants on aggregate have forfeited their deposits. From 1951 to 1989 elections the forfeiture percentage of the INC was below $1.00 \%$ and this percentage grew during the latter half viz. from 1991 to 2014 . On aggregate $27.87 \%$ contestants of BJP forfeited their deposits, followed by $80.72 \%$ BSP contestants, $45.02 \%$ contestants of CPI and $25.04 \%$ CPM contestants. The rest of the national parties forfeited their deposits on an aggregate of $53.18 \%$ of their contestants.

Table-9 Status of Electors in each General Election

\begin{tabular}{|c|c|c|c|c|c|c|c|c|}
\hline \multirow{2}{*}{ Year } & \multicolumn{3}{|c|}{ Total Electors } & \multicolumn{2}{c|}{ Turnout and Gender Share Percentage } & \multicolumn{2}{c|}{ Gender Turnout } \\
\cline { 2 - 8 } & Male (\%) & Female (\%) & Total & Male (\%) & Female (\%) & Total (\%) & M (\%) & F (\%) \\
\hline 1951 & NA & NA & N173212343 & NA & NA & $\begin{array}{c}105950083 \\
(44.87)\end{array}$ & NA & NA \\
\hline 1957 & NA & NA & $\# 193652179$ & NA & $\begin{array}{c}120513915 \\
(45.44)\end{array}$ & NA & NA \\
\hline 1962 & $\begin{array}{c}113944234 \\
(52.67)\end{array}$ & $\begin{array}{c}102417335 \\
(47.33)\end{array}$ & 216361569 & $\begin{array}{c}72212114 \\
(60.23)\end{array}$ & $\begin{array}{c}47692170 \\
(39.77)\end{array}$ & $\begin{array}{c}119904284 \\
(55.42)\end{array}$ & 63.37 & 46.56 \\
\hline 1967 & $\begin{array}{c}129568604 \\
(51.78)\end{array}$ & $\begin{array}{c}120638797 \\
(48.22)\end{array}$ & 250207401 & $\begin{array}{c}86460563 \\
(56.62)\end{array}$ & $\begin{array}{c}66264048 \\
(43.38)\end{array}$ & $\begin{array}{c}152724611 \\
(61.04)\end{array}$ & 66.72 & 54.92 \\
\hline 1971 & $\begin{array}{c}143564829 \\
(52.35)\end{array}$ & $\begin{array}{c}130624303 \\
(47.65)\end{array}$ & 274189132 & $\begin{array}{c}87382907 \\
(57.67)\end{array}$ & $\begin{array}{c}64153895 \\
(42.33)\end{array}$ & $\begin{array}{c}151536802 \\
(55.27)\end{array}$ & 60.86 & 49.11 \\
\hline 1977 & $\begin{array}{c}167019151 \\
(52.00)\end{array}$ & $\begin{array}{c}154155176 \\
(48.00)\end{array}$ & 321174327 & $\begin{array}{c}109609940 \\
(56.43)\end{array}$ & $\begin{array}{c}84653975 \\
(43.57)\end{array}$ & $\begin{array}{c}194263915 \\
(60.49)\end{array}$ & 65.62 & 54.91 \\
\hline 1980 & $\begin{array}{c}185539439 \\
(52.08)\end{array}$ & $\begin{array}{c}170665890 \\
(47.92)\end{array}$ & 356205329 & $\begin{array}{c}115357604 \\
(56.90)\end{array}$ & $\begin{array}{c}87395289 \\
(43.10)\end{array}$ & $\begin{array}{c}202752893 \\
(56.92)\end{array}$ & 62.17 & 51.20 \\
\hline 1984 & $\begin{array}{c}196730499 \\
(51.83)\end{array}$ & $\begin{array}{c}182810109 \\
(48.17)\end{array}$ & 379540608 & $\begin{array}{c}134122952 \\
(55.60)\end{array}$ & $\begin{array}{c}107123935 \\
(44.40)\end{array}$ & $\begin{array}{c}241246887 \\
(63.56)\end{array}$ & 68.17 & 58.59 \\
\hline 1989 & $\begin{array}{c}262045142 \\
(52.52)\end{array}$ & $\begin{array}{c}236860987 \\
(47.48)\end{array}$ & 498906129 & $\begin{array}{c}173290798 \\
(56.08)\end{array}$ & $\begin{array}{c}135759697 \\
(43.92)\end{array}$ & $\begin{array}{c}30950495 \\
(61.95)\end{array}$ & 66.13 & 57.31 \\
\hline 1991 & $\begin{array}{c}261832499 \\
(52.53)\end{array}$ & $\begin{array}{c}236531302 \\
(47.47)\end{array}$ & 498363801 & $\begin{array}{c}161246545 \\
(57.04)\end{array}$ & $\begin{array}{c}121454397 \\
(42.96)\end{array}$ & $\begin{array}{c}282700942 \\
(56.73)\end{array}$ & 61.58 & 51.34 \\
\hline 1996 & $\begin{array}{c}309815776 \\
(52.28)\end{array}$ & $\begin{array}{c}282756512 \\
(47.72)\end{array}$ & 592572288 & $\begin{array}{c}192279757 \\
(56.01)\end{array}$ & $\begin{array}{c}151028333 \\
(43.99)\end{array}$ & $\begin{array}{c}343308090 \\
(57.94)\end{array}$ & 62.06 & 53.41 \\
\hline 1998 & $\begin{array}{c}316692789 \\
(52.26)\end{array}$ & $\begin{array}{c}289187403 \\
(47.74)\end{array}$ & 605880192 & $\begin{array}{c}208596815 \\
(55.57)\end{array}$ & $\begin{array}{c}166844924 \\
(44.43)\end{array}$ & $\begin{array}{c}37541739 \\
(61.97)\end{array}$ & 65.86 & 57.69 \\
\hline 1999 & $\begin{array}{c}323813667 \\
(52.26)\end{array}$ & $\begin{array}{c}295723180 \\
(47.74)\end{array}$ & 619536847 & $\begin{array}{c}207130100 \\
(55.73)\end{array}$ & $\begin{array}{c}164539004 \\
(44.27)\end{array}$ & $\begin{array}{c}371669104 \\
(59.99)\end{array}$ & 63.96 & 55.63 \\
\hline
\end{tabular}




\begin{tabular}{|c|c|c|c|c|c|c|c|c|}
\hline 2004 & $\begin{array}{c}349490864 \\
(52.04)\end{array}$ & $\begin{array}{c}321997066 \\
(47.96)\end{array}$ & 671487930 & $\begin{array}{c}217234104 \\
(55.71)\end{array}$ & $\begin{array}{c}172714226 \\
(44.29)\end{array}$ & $\begin{array}{c}389948330 \\
(58.07)\end{array}$ & 62.15 & 53.63 \\
\hline 2009 & $\begin{array}{c}374758801 \\
(52.26)\end{array}$ & $\begin{array}{c}342226300 \\
(47.74)\end{array}$ & 716985101 & $\begin{array}{c}191028997 \\
(45.84)\end{array}$ & $\begin{array}{c}225765026 \\
(54.16)\end{array}$ & $\begin{array}{c}416794023 \\
(58.19)\end{array}$ & 50.97 & 65.96 \\
\hline $2014 *$ & $\begin{array}{c}437035372 \\
(52.39)\end{array}$ & $\begin{array}{c}397018915 \\
(47.59)\end{array}$ & 834082814 & $\begin{array}{c}292826408 \\
(52.84)\end{array}$ & $\begin{array}{c}260192272 \\
(46.95)\end{array}$ & $\begin{array}{c}554175255 \\
(66.44)\end{array}$ & 67.00 & 65.54 \\
\hline Avg. & $\begin{array}{c}\mathbf{3 5 7 1 8 5 1 6 6 6} \\
\mathbf{( 5 2 . 2 5 )}\end{array}$ & $\begin{array}{c}\mathbf{3 2 6 3 6 1 3 2 7 5} \\
\mathbf{( 4 7 . 7 4 )}\end{array}$ & $\mathbf{6 8 3 5 4 9 3 4 6 8}$ & $\begin{array}{c}\mathbf{2 2 4 8 7 7 9 6 0 4} \\
\mathbf{( 5 4 . 7 7 )}\end{array}$ & $\begin{array}{c}\mathbf{1 8 5 5 5 8 1 1 9 1} \\
\mathbf{( 4 5 . 1 9 )}\end{array}$ & $\begin{array}{c}\mathbf{4 1 0 5 5 1 7 3 7 0} \\
\mathbf{( 6 0 . 0 6 )}\end{array}$ & $\mathbf{6 2 . 9 5}$ & $\mathbf{5 6 . 8 5}$ \\
\hline
\end{tabular}

NA-Not Available

(Note-Average percentage has been drawn out by excluding the data of 1951 and 1962 for being NA under all heads)

*during 2014 GE third gender was also included having 28572 electorates, out of which 1968 exercised their right.

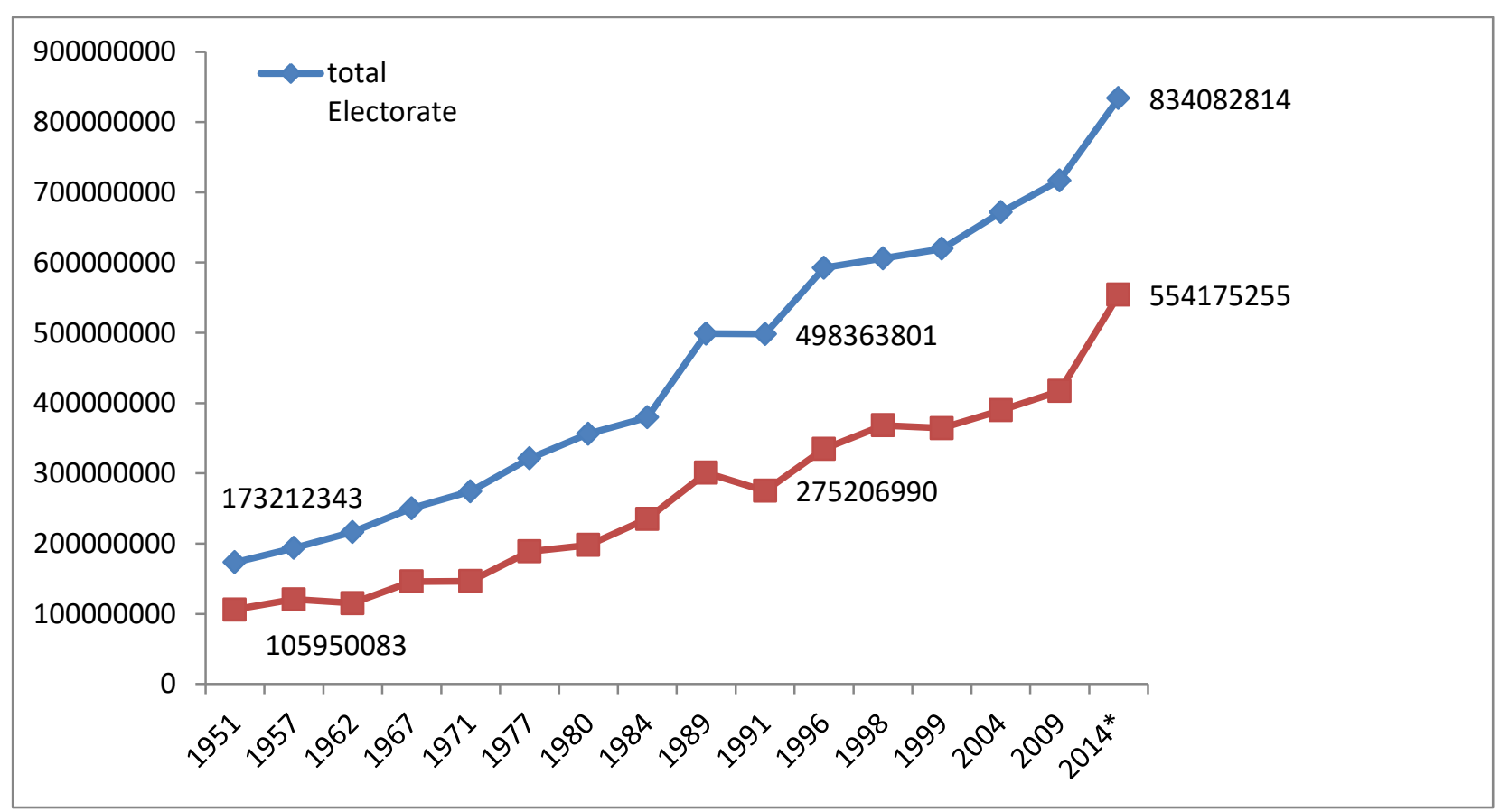

Figure 5 Election to election basis electorate size and votes cast.

Above tabulation reflects the total electorate of the country during each individual election and the subsequent voter turnout thereof in each general election, both collectively and on the gender basis. As per the natural sex ration there are 105 females to per 100 males, but if look at the table, we can see, of the total electors during all the years of elections, there is male dominance over females with an average of $52.25 \%$ male electors over $47.74 \%$ female electors. The average voter turnout during all the elections remained at $60.06 \%$ with maximum voter turnout $66.44 \%$ observed in the year 2014 and minimum $44.87 \%$ during the year 1951 . Compared to $54.77 \%$ male voter turnout $45.19 \%$ females exercised their right, which again somewhere reflects the male dominance of Indian society and the need thereof in further encouraging the fairer sex to actively participate in the electoral process of the country. At the gender level, on average, $62.95 \%$ male electorate exercised their electoral right, while as $56.85 \%$ females cast their votes.

Table-10 Share of votes between National and State Political Parties along with Independents

\begin{tabular}{|c|c|c|c|c|c|}
\hline \multirow{2}{*}{ Year } & Total & \multicolumn{4}{|c|}{ Vote Share \& Percentage } \\
\cline { 3 - 6 } & Seats & $*$ NP (\%) & $*$ SP (\%) & $*$ IN (\%) & Total \\
\hline 1951 & 489 & $80516821(76.00)$ & $8583173(8.10)$ & $16850089(15.90)$ & 105950083 \\
\hline 1957 & 494 & $88069597(73.80)$ & $9160069(7.56)$ & $23284249(19.32)$ & 120513915 \\
\hline 1962 & 494 & $90407285(78.50)$ & $12039117(10.45)$ & $12722488(11.05)$ & 115168890 \\
\hline 1967 & 520 & $111051515(76.13)$ & $14708944(10.08)$ & $20106051(13.78)$ & 145866510 \\
\hline 1971 & 518 & $114119663(77.84)$ & $20202984(13.79)$ & $12279629(8.38)$ & 146602276 \\
\hline 1977 & 542 & $159962381(84.67)$ & $38764490(9.83)$ & $10393617(5.50)$ & 188917504 \\
\hline
\end{tabular}




\begin{tabular}{|c|c|c|c|c|c|}
\hline 1980 & 529 & $168289769(85.07)$ & $16816995(7.50)$ & $12717510(6.43)$ & 197824274 \\
\hline 1984 & 514 & $187682455(79.80)$ & $28877951(12.220$ & $18623803(7.92)$ & 235184209 \\
\hline 1989 & 529 & $238620936(79.33)$ & $46361706(15.41)$ & $15793781(5.25)$ & 300776423 \\
\hline 1991 & 521 & $221968051(80.65)$ & $41797251(15.19)$ & $11441688(4.16)$ & 275206990 \\
\hline 1996 & 543 & $231345934(69.08)$ & $82485795(24.63)$ & $21041557(6.28)$ & 334873286 \\
\hline 1998 & 543 & $250407382(67.98)$ & $109249366(29.66)$ & $8719952(2.37)$ & 368376700 \\
\hline 1999 & 543 & $244564056(37.11)$ & $109876852(30.15)$ & $9996386(2.74)$ & 364437294 \\
\hline 2004 & 543 & $245123639(62.89)$ & $128106245(32.86)$ & $16549900(4.25)$ & 389779784 \\
\hline 2009 & 543 & $265247905(63.58)$ & $130263690(31.22)$ & $21647686(5.20)$ & 417159281 \\
\hline 2014 & 543 & $332494491(59.99)$ & $204937045(36.98)$ & $16743719(3.02)$ & 554175255 \\
\hline Avg & & $\mathbf{3 0 2 9 8 7 1 8 8 0 ( 7 1 . 1 1 )}$ & $\mathbf{1 0 0 2 2 3 1 6 7 3 ( 2 3 . 5 2 )}$ & $\mathbf{2 4 8 9 1 2 1 0 5 ( 5 . 8 4 )}$ & $\mathbf{4 2 6 0 8 1 2 6 7 4}$ \\
\hline
\end{tabular}

NP-National Parties, SP-State Parties, IND-Independents

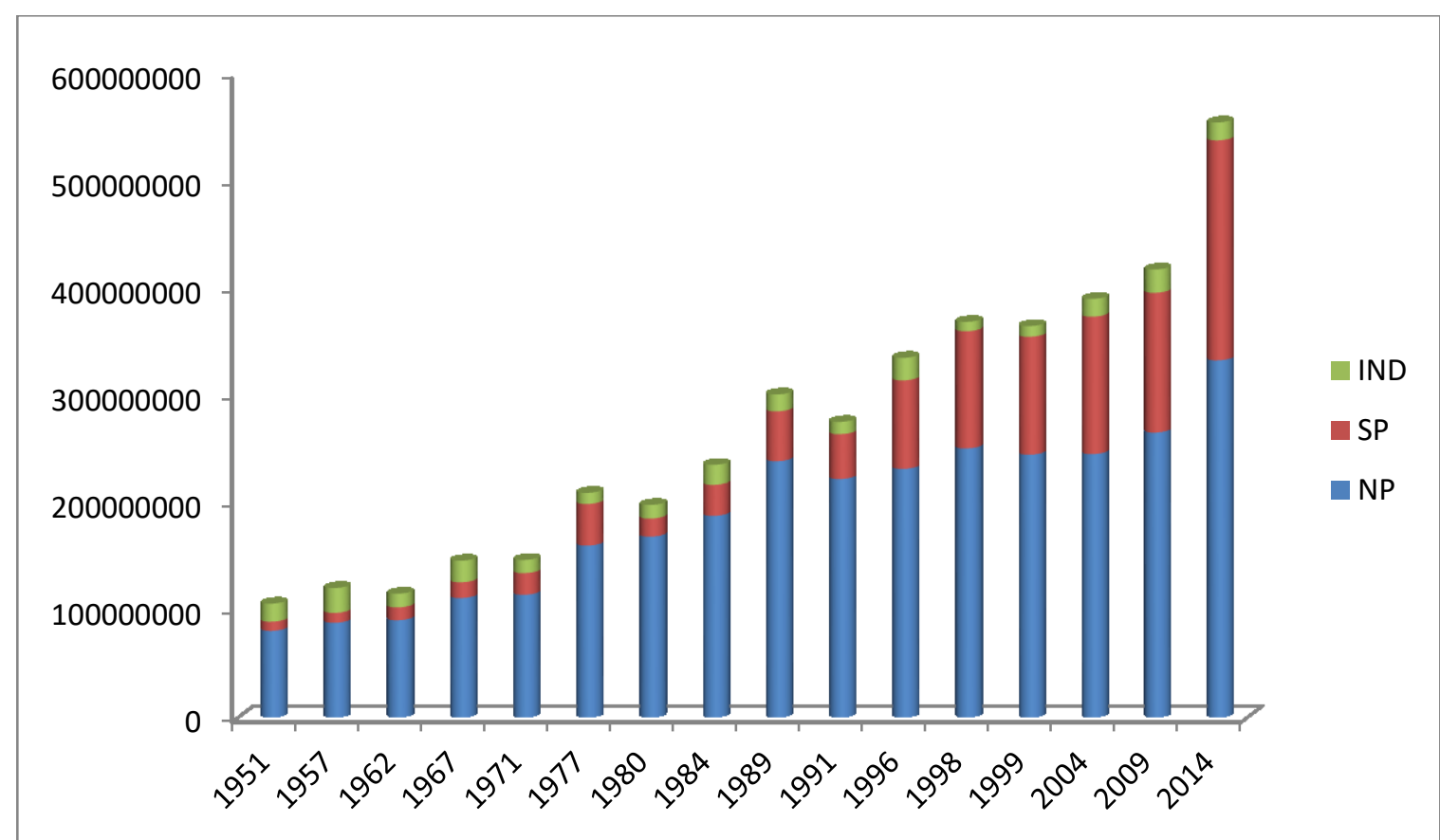

Figure 6 Election to election depiction of vote share among national, state level political parties and independents

There are a number of recorded instances in the electoral process, whereby a party having a major share of votes suffers defeat and a party with a lesser voter percentage emerges winner. Well, these facts can be owed to different reasons. Given this fact in the above tabulation attempt has been made to reflect the figures about the percentage of vote share among national parties, state level parties and the independents. As reflected in the figures, during all the general elections, national parties have emerged with a woofing average vote share percentage of $71.11 \%$, followed by state level political parties with a share percentage of $23.52 \%$ and independents with $5.84 \%$. Again, if we compare these figures with the overall winning percentage of candidates, then $80.45 \%$ elected candidates are from the national parties, $16.90 \%$ are from state level parties, and 2.64\% independents. The figures, although are in proportion to the vote share difference, but not in proportion to vote share obtained.

Table-11 Percentage of seats contested by Major National Parties

\begin{tabular}{|c|c|c|c|c|c|c|c|c|c|}
\hline \multirow{2}{*}{ Year } & \multirow{2}{*}{$\begin{array}{l}\text { No of } \\
\text { Seats }\end{array}$} & \multicolumn{6}{|c|}{ Maior National Parties } & \multirow{2}{*}{$\begin{array}{c}\text { CNP } \\
\text { (\% Share) }\end{array}$} & \multirow[t]{2}{*}{ Total } \\
\hline & & BJP (\%) & BSP (\%) & CPI (\%) & CPM (\%) & INC (\%) & Others (\%) & & \\
\hline 1951 & $\# 489$ & - & - & $49(10.02)$ & - & 489 (97.95) & $689(140.89)$ & $1227(65.47)$ & 1874 \\
\hline 1957 & $\# 494$ & - & - & $110(22.26)$ & - & $490(99.19)$ & $319(64.57)$ & $919(60.50)$ & 1519 \\
\hline 1962 & 494 & - & - & $137(27.73)$ & - & $488(98.78)$ & $644(130.36)$ & $1269(63.42)$ & 1985 \\
\hline 1967 & 520 & - & - & $109(20.96)$ & $59(11.34)$ & $516(99.23)$ & $658(126.53)$ & $1342(56.64)$ & 2369 \\
\hline 1971 & 518 & - & - & $87(16.79)$ & $85(16.40)$ & $441(85.13)$ & $610(117.76)$ & $1223(43.92)$ & 2784 \\
\hline 1977 & 542 & - & - & $91(16.78)$ & $53(9.77)$ & $492(90.77)$ & $424(78.22)$ & $1060(43.46)$ & 2439 \\
\hline
\end{tabular}




\begin{tabular}{|c|c|c|c|c|c|c|c|c|c|}
\hline 1980 & 529 & - & - & $47(8.88)$ & $64(12.09)$ & $492(93.00)$ & $938(177.31)$ & 1541 (33.29) & 4629 \\
\hline 1984 & 514 & $224(43.57)$ & - & $61(11.86)$ & $59(11.47)$ & 491 (95.52) & 409 (79.57) & $1244(23.41)$ & 5312 \\
\hline 1989 & 529 & $225(42.53)$ & - & $50(9.45)$ & $64(12.09)$ & $510(96.40)$ & $529(100)$ & $1378(22.37)$ & 6160 \\
\hline 1991 & 521 & $468(89.82)$ & - & $42(8.06)$ & $60(11.51)$ & 487 (93.47) & $775(148.75)$ & $1832(21.13)$ & 8668 \\
\hline 1996 & 543 & $471(86.74)$ & - & $43(7.91)$ & $75(13.81)$ & $529(97.42)$ & $699(128.72)$ & $1817(13.02)$ & 13952 \\
\hline 1998 & 543 & $388(71.45)$ & $251(46.22)$ & $58(10.68)$ & $71(13.07)$ & $477(87.84)$ & $248(45.67)$ & $1493(31.43)$ & 4750 \\
\hline 1999 & 543 & $339(62.43)$ & $225(41.43)$ & $54(9.94)$ & $72(13.25)$ & $453(83.42)$ & $156(28.72)$ & $1299(27.94)$ & 4648 \\
\hline 2004 & 543 & $364(67.03)$ & $435(80.11)$ & $34(6.26)$ & $69(12.70)$ & $417(76.79)$ & $32(5.89)$ & $1351(24.85)$ & 5435 \\
\hline 2009 & 543 & $433(79.74)$ & $500(92.08)$ & $56(10.31)$ & $82(15.10)$ & $440(81.03)$ & $112(20.62)$ & $1623(20.11)$ & 8070 \\
\hline 2014 & 543 & $428(79.37)$ & $503(92.63)$ & $67(12.33)$ & $93(17.12)$ & $464(85.45)$ & $36(6.62)$ & $1591(19.28)$ & 8251 \\
\hline Avg & & $\begin{array}{c}3340(371)^{*} \\
(69.26) \#\end{array}$ & $\begin{array}{c}1914(382)^{*} \\
(70.49) \#\end{array}$ & $\begin{array}{c}1095(68)^{*} \\
(13.02) \#\end{array}$ & $\begin{array}{c}906(69)^{*} \\
(13.07) \#\end{array}$ & $\begin{array}{c}7676(479) * \\
(91.29) \#\end{array}$ & $\begin{array}{c}278(454)^{*} \\
(86.56) \#\end{array}$ & $\begin{array}{l}22209 \\
(26.80)\end{array}$ & 82845 \\
\hline
\end{tabular}

(Note-Average percentage has been drawn out of total elections contested by each individual party)

(*-Reflects the average candidates fielded by parties during all the elections \& have been rounded off either to the next higher or to previous highest)

\# Percentage of seats contested by each national party

CNP-Contestants from National Parties, BJP-Bhartiya Janta Party, BSP-Bahujan Samaj Party, CPI-Communist Party of India, CPM-Communist Party of India (Marxist), INC-Indian National Congress, IND-Independents, Avg-Average

The general notion and the accepted belief about the political party of national or state level repute is augmented by the presence of party at national or state level. But if we go through the figures reflected in the above table about the presence of major political parties in the country, then the parties like the Communist Party of India (CPI) and Communist Party of India, Marxist (CPM) somewhere do not fulfil the status of being recognized as national parties, firstly for their limited presence in the country and secondly by contesting on average $13.02 \%$ and $13.07 \%$ seats respectively. Apart from Indian National Congress (INC), Bhartiya Janta Party (BJP) and Bahujan Samajwadi Party (BSP) are the other two major national level political parties in the country. INC is on the national scene form 1951 having contested on average $91.29 \%$ seats, while as BJP and BSP have come into the scene from 1984 and 1998, which on average contested $69.26 \%$ and $70.49 \%$ seats respectively during all the general elections they have fought. Although CPI and CPM have been contesting general elections since 1951 and 1967 respectively, but they couldn't make it big all these years for the fact Indian masses uphold their ideology as borrowed from countries like Russia and China and their presence is mostly confined to the limited parts of north east, West Bengal and Kerala.

Table-12 Percentage of votes Obtained by Major National Parties

\begin{tabular}{|c|c|c|c|c|c|c|c|c|c|c|}
\hline \multirow{2}{*}{ Year } & \multirow{2}{*}{$\begin{array}{l}\text { No of } \\
\text { Seats }\end{array}$} & \multicolumn{8}{|c|}{ Major National Parties } & \multirow{2}{*}{ Total votes } \\
\hline & & BJP & BSP & CPI & CPM & INC & ONP & SP & IND & \\
\hline 1951 & $\# 489$ & - & - & 3.29 & - & 44.99 & 27.71 & 8.10 & 15.90 & 105950083 \\
\hline 1957 & $\# 494$ & - & - & 8.92 & - & 47.78 & 16.38 & 7.60 & 19.32 & 120513915 \\
\hline 1962 & 494 & - & - & 9.94 & - & 44.72 & 23.83 & 10.45 & 11.05 & 115168890 \\
\hline 1967 & 520 & - & - & 5.11 & 4.28 & 40.78 & 25.96 & 10.08 & 13.78 & 145866510 \\
\hline 1971 & 518 & - & - & 4.73 & 5.12 & 43.68 & 24.32 & 13.89 & 8.38 & 146602276 \\
\hline 1977 & 542 & - & - & 2.82 & 4.29 & 34.52 & 43.04 & 9.83 & 5.50 & 188917504 \\
\hline 1980 & 529 & - & - & 2.49 & 6.24 & 42.69 & 76.33 & 8.50 & 6.43 & 197824274 \\
\hline 1984 & 514 & 7.74 & - & 2.71 & 5.87 & 49.10 & 14.38 & 12.28 & 7.92 & 235184209 \\
\hline 1989 & 529 & 11.36 & - & 2.57 & 6.55 & 39.53 & 19.33 & 15.41 & 5.25 & 300776423 \\
\hline 1991 & 521 & 20.11 & - & 2.49 & 6.16 & 36.26 & 15.63 & 15.11 & 4.16 & 275206990 \\
\hline 1996 & 543 & 20.29 & - & 1.97 & 6.12 & 28.80 & 11.90 & 24.63 & 6.28 & 334873286 \\
\hline 1998 & 543 & 25.59 & 4.67 & 1.75 & 5.16 & 25.82 & 5.00 & 29.66 & 2.37 & 368376700 \\
\hline 1999 & 543 & 23.75 & 4.16 & 1.48 & 5.40 & 28.30 & 4.01 & 30.15 & 2.74 & 364437294 \\
\hline 2004 & 543 & 22.16 & 5.33 & 1.41 & 5.66 & 26.53 & 1.80 & 32.86 & 4.25 & 389779784 \\
\hline 2009 & 543 & 18.80 & 6.17 & 1.43 & 5.33 & 28.55 & 3.31 & 31.22 & 5.20 & 417159281 \\
\hline 2014 & 543 & 30.97 & 4.14 & 0.78 & 3.24 & 19.29 & 1.55 & 37.01 & 3.02 & 554175255 \\
\hline Avg & & 20.08 & 4.89 & 3.36 & 5.34 & 36.33 & 19.65 & 18.54 & 7.59 & 266300792 \\
\hline
\end{tabular}

(Note-Average percentage has been drawn out of total elections contested by each individual party)BJP-Bhartiya Janta Party, BSP-Bahujan Samaj Party, CPI- Communist Party of India, CPM-Communist Party of India (Marxist), INCIndian National Congress, ONP-Other National Parties, SP-State Parties, IND-Independents, Avg-Average 


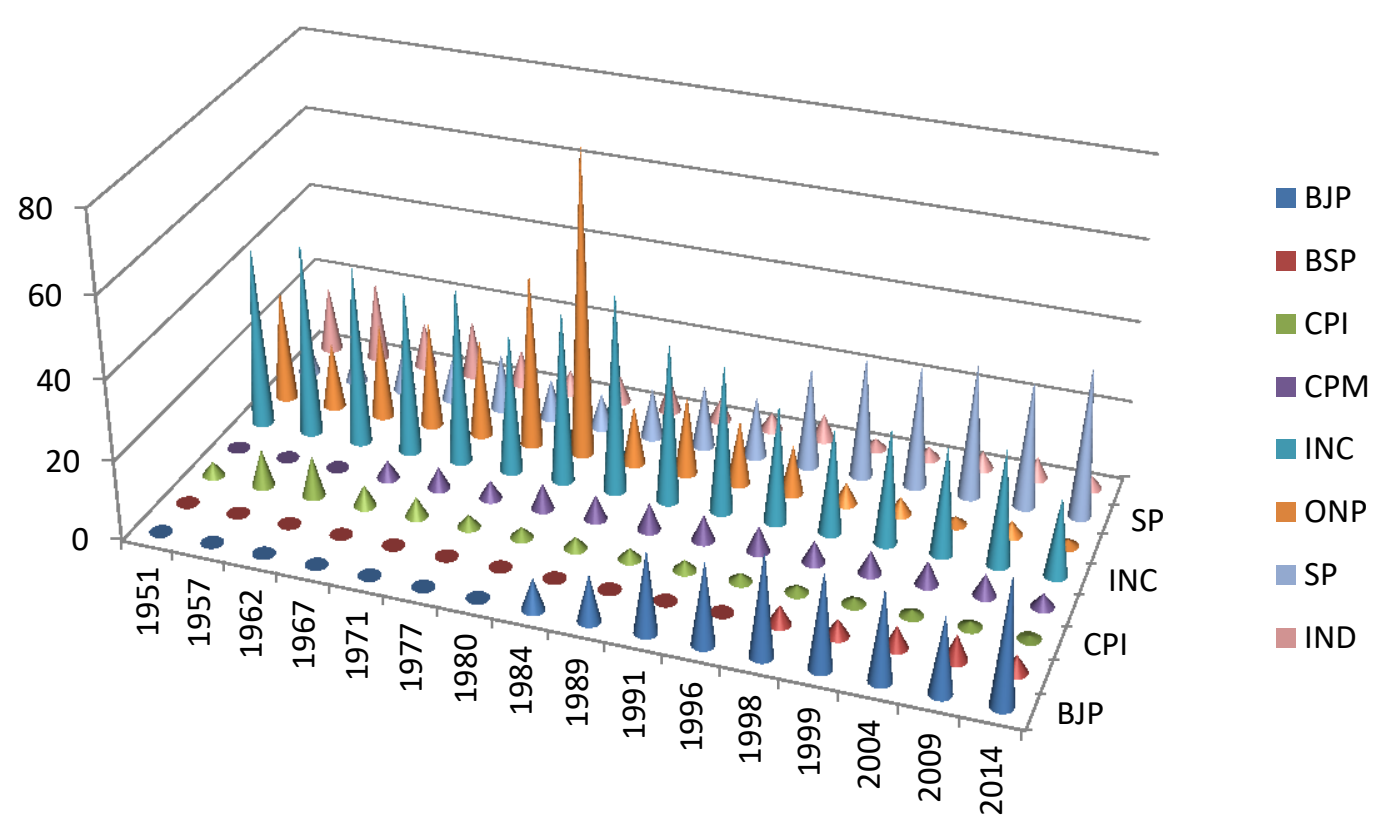

The presence of political party among masses also gets reflected by the percentage of votes obtained by a particular political party during an election. Even one can easily come across an instance whereby a party may have obtained better percentage of votes over rivals, but still they end up as losers, which can be owed to the fact for not having secured the proportionate vote in maximum constituencies. Accordingly, in the above tabulation attempt has been made to assess the percentage of votes obtained by major national political parties to that of state and other political parties during all elections and the average percentage of votes obtained during all general elections held during the period of study. The average percentage of votes obtained by INC during all elections is $36.33 \%$ the maximum among all other national and state level political parties, but still the worrying aspect for INC is its declining percentage of votes obtained as we move from 1951 to 2014. BJP on average has obtained $20.08 \%$ votes during all the elections and the better part of BJP is that over a period of time it has emerged as one of the major opposing force for INC, which is still the dominant political party of the county. State parties, on average have received $18.54 \%$ votes and Independents $7.59 \%$ votes. CPI and CPM despite having a long presence in the Indian polity could never make it big and this gets better reflected by their abysmal vote share of $3.36 \%$ and $5.34 \%$ respectively.

\section{DISCUSSION AND CONCLUSION}

Multiparty system of India can be considered as one of the weakest link in Indian polity, which only helps towards the contribution of weak and instable political system of country. Needless to say that political instability affects the overall growth and development of nation and encourages more undesirable practices, which include corruption \& nepotism and furthers barriers in the name of cast, colour, creed, culture, region, religion etc. Since there is no check on the upcoming political parties and other political formations, so this exponential growth of political parties will continue in years to come, without severing any fundamental or basic purpose of the masses of the country. Need is to look into this unprecedented growth of political parties of the country by having a check on their growth by putting in place some tough measures for any desirable party to be recognized as a political party both at the national and the federal level.

Reservation of seats for disadvantaged sections of the society by and large seems a good idea and should be carried forward at least till the time these sections be rated at par with advantaged sections of society. There is every likeliness, that even if at some point of time the reservations are removed the cast ridden society of India will help it to survive on its own, by choosing people from their own sections only. 
Owing to the huge population of India, an aggregate of $60.06 \%$ voter turnout can be considered good for many reasons, be it presence of nearly $40 \%$ illiteracy, $75 \%$ rural life, gender based differences, etc., but the fact is there is a need to sensitize people about their democratic right and the power they have in their hands which they can exercise to suit their collective interests. Indian woman somewhere still seems busy in the kitchen, bearing, rearing \& caring of children, more a domestic help to look after cattle, farms and fields, as such finding little time to participate actively in electoral process of the country.

National political parties of India always had a lions share in both seats won and the percentage of votes obtained during general elections. On aggregate over $80 \%$ seats and oner $75 \%$ votes have gone into the kitty of national political parties, but that does not belittle the importance of federal parties of country, as most of the times these smaller regional parties prove the king makers and this as a result, these parties most of the time get engaged in exploiting things to suit to their individual interests and become hurdle many a times in the decision making process, which also results in creating the atmosphere of political instability in the country. Political stability is foremost required to ensure the growth and development of the nation, especially in the $21^{\text {st }}$ century where economic interdependence among nations cannot be overlooked. There is a need to create stable political atmosphere in the country whereby people may show interest in making investments in other nation and doing other businesses.

Post 1990, coalition politics has become the order of the Indian Polity. UPA and NDA are the two main political amalgams in which INC and BJP are the central parties around whom the rest of the country's politics revolves

\section{References:-}

[1] Geo-Hack-India. (n.d). Retrieved July 13, 2013 from http://tools.wmflabs.org/geohack/geohack.php?pagename=India\&params=28_36.8_N_77_12. 5_E_type:country

[2] Election Commissioner of India. (n.d). Retrieved August 21, 2015 from http://eci.gov.in/eci_main1/index.aspx

[3] Indian Parliament. (n.d). Accessed on August 2, 2013. Available at http://www.parliamentofindia.nic.in/

[4] Election Commissioner of India. (n.d). Retrieved August 21, 2015 from http://eci.gov.in/eci_main1/index.aspx

[5] Losty, J. P., \& Roy, M. (2012). Mughal India: Art, Culture and Empire

[6] Indian Parliament. (n.d). Accessed on August 2, 2013. Available at http://www.parliamentofindia.nic.in/

[7] Ibid Election Commissioner of India. (n.d). Retrieved July 13, 2013 from http://eci.gov.in/eci_main1/index.aspx

[8] Sharon F. Lean, Nicole Elise Gerring. (2013). Liberia's 2011 General Elections. Electoral Studies. 32, 204-208

[9] Reif, Karlheinz. (2013). National Electoral Cycles and European Election 1979 and 1984.

[10] Gallagher, Michael. (2013). Proportionality, disproportionality and electoral systems.

[11] Paul R. Abramson., John H. Aldrich., Abraham. Diskin., Aaron M. Houck., Renan Levine f, Thomas J. Scotto. (2013). The British General Elections of 2010 under different voting rules. Electoral Studies. 32, 134-139

[12] Tim, Haughton., Alenka, Kra_sovec. (2013). The 2011 parliamentary elections of Slovenia. Electoral Studies. 32, 201-204

[13] Sean, Mueller., Paolo, Dardanelli. (2013). The parliamentary and executive elections in Switzerland, 2011. Electoral Studies. 32, 197-208

[14] MIWA, H. I. R. O. K. I. (1997). GENERAL ELECTION IN INDIA. Political Science Annual, 185. 
[15] R. Pandita, "Scenario of Public Participation in Assembly Elections of Jammu \& Kashmir: A Study (1962-2008)", International Letters of Social and Humanistic Sciences, Vol. 27, pp. 118, May. 2014.

[16] R. Pandita, "Jammu \& Kashmir's Repeated Reaffirmed Faith in the Democratic Setup of India: A Study of the State's Public Participation in the General Elections of India (19672014)", International Letters of Social and Humanistic Sciences, Vol. 51, pp. 125-138, May. 2015

[17] R. Pandita, "Participation and Performance of Women Candidates in the General Elections of India: An Analytical Study (1951-2009)", International Letters of Social and Humanistic Sciences, Vol. 28, pp. 128-149, May. 2014

[18] Tinker, I., \& Walker, M. (1956). The First General Elections in India and Indonesia. Far Eastern Survey, 25(7), 97-110.

[19] Kaviraj, S. (1997). The general elections in India. Government and Opposition, 32(1), 3-24.

[20] Kumar, S. (2002). Reforming Indian electoral process. Economic and Political Weekly, 34893491. 